\title{
'Abd Allah Ibn Al-Zubayr and His Career as Caliph
}

Prof. Dr. Mehmet Mehdi Ilhan*

Abstract

'Abd Allah b. al-Zubayr was raised by 'A'isha in the Prophet's (s.a.s.) house. Safiyyah, the Prophet's maternal aunt was his paternal grandmother, 'A'isha's sister Asma was his mother, and Abu Bakr his maternal grandfather. 'Abd Allah b. al-Zubayr's upbringing and lineage played an important role throughout his life and future career as caliph. Although 'Abd Allah b. al-Zubayr was undeniably close to ' $A$ 'isha, a very reliable source for the sunna and the traditions of the Prophet, his loyalty to the teachings of the Prophet and particularly the warning to those who attribute to the Prophet what he had not said that they would be sent to hell determined his choice of only 33 hadith to transmit. His love for the house of the Prophet and his grandfather Abu Bakr made him a staunch defender of the office of caliphate when he saw it abused by Mu'awiyah and his son Yazid.

'Abd Allah b. al-Zubayr ruled over Hijaz and the Eastern provinces from Mecca for nine years. The people of Iraq, Hijaz, and a large part of Syria paid him homage as caliph. After his death in 692 A.D., the caliphate of 'Abd al-Malik b. Marwan was confirmed.

In this paper I will deal with the life and career of 'Abd Allah b. al-Zubayr and show how the Prophet's teachings were reflected in his character and behaviour.

Key words: 'Abd Allah ibn al-Zubayr, Zubayrids, Islam, caliphate, Umayyad, civil war.

'Abd Allah b. al-Zubayr was the first child born among the Muslim emigrants of Medina (Muhajirun) in the second year of Hidjra (about twenty months after Hidjra: Sha'ban 2/February 624) ${ }^{1}$. The Prophet blessed him and fed him with a piece of date that he chewed before his mother breast-fed him. ${ }^{2}$ His birth was good tidings for the Muslims and an unpleasant answer to the menace of the Jews. ${ }^{3}$ He had a strong lineage and his father al-Zubayr b. 'Avvam, whom the Prophet considered his apostle ${ }^{4}$ was one of the first five adult males converted to

* Australian National University, Canberra \& Istanbul Sabahattin Zaim University.

1 According to al-Waqidi he was born in the village of Quba, the immediate vicinity of Medina in the month of Shawwal, see Ibn 'Asakir, Tarikh Dimashq al-Kebir (Beyrouth: Dar Ihya al-Turath al-'Arabi 2001): vol. 30, 115-118.

2 Ibn al-Kathir, Abu'l-Fifa al-Hafiz ibn Kathir al-Dimashqi, al-Bidayah wa al-Nihayah, (Beirut: Dar al-Khayr 1996): vol. II, 627; al-Natur, Shahade, 'Abd Allah b. al-Zubayr ve'l-Intifade al-Sevriyye fi 'ahdi Beni Umayyah, (Amman: Dar Ibn Rushd 1984): 18.

3 Ibn 'Asakir, 119-120; Sha'ban, Hilmi 'Ali, 'Abdullah bin al-Zubayr (Beirut 1991): 9-10.

4 Ibn al-Kathir, vol. II, 346. 
Islam. ${ }^{1}$ At the time there were no births for the emigrants, and the Jews were using this against the Muslims, claiming that they had become barren after their migration to Medina. ${ }^{2}$

His full name was Abu Kubayb 'Abd Allah b. al-Zubayr b. Al-'Awwam b. Khuvaylid b. Asad b. 'Abd al-'Uzza b. Kusayy b. Kilab b. Murrah b. Ka'ab b. Luiyy b. Ghalib b. Fihr Al-Asadi al-Qurayshi. ${ }^{3} \mathrm{He}$ was from 'Abd Al-'Uzza's clan of the Qurayshites. His nickname was Abu Bakr, given to him by the Prophet after his maternal grandfather. 'Abd Allah b. al-Zubayr had matrilineal and patrilineal links to both the family of the Prophet and the family of Abu Bakr. ${ }^{4}$ His paternal grandmother Safiyyah was the Prophet's maternal aunt, ${ }^{5}$ the first Muslim to kill an infidel in service to Allah. ${ }^{6}$ Khadice, the Prophet's wife, was the paternal aunt of his father al-Zubayr b. al-'Avvam. ${ }^{7}$ Thus, through his father he was closely related to al-Hasan and al-Husayn, Khadija's grandsons. His mother Asma, a very wise woman, was the elder daughter of Abu Bakr and elder sister of 'A'isha. His aunt 'A'isha brought him up in the Prophet's house as she herself did not have a child. He was the dearest person to her after the Prophet and her father Abu Bakr. 'A'isha, therefore, is also known as Umm 'Abd Allah. ${ }^{8}$

So, with such a privileged birth and nobility as well as his upbringing, it is no wonder he became the staunchest defender of the house of the Prophet and the office of the caliphate. He stood in opposition to the house of Umayyad, won the support of Kalb, an Umayyad tribe, and worked very hard to seize power from the Umayyads. ${ }^{9}$

As a young boy, he participated in the Islamic wars of conquest. He accompanied his father and mother ${ }^{10}$, at the age of fourteen, to Yarmuk where he watched

1 Ibn al-Kathir, vol. II, 369.

2 H.D. Yıldız, (ed.), Büyük İslam Tarihi, (Istanbul: Çağ Yayınları, 1989): vol. I, 280; Ibrahim, Sabir b. 'Abduh, Al-Zubayr b. al-'Awwam, (Kuwait 1971): 16-17; 'Ali Hasan al-Kharputli, 'Abdullah b. al-Zubayr, AlMu'essetu al-Misriyye al-'Amme, n.d., 13-14

3 Ibn Khallikan, Vefayatu'l-a'yan ve Enba'i enba' al-Zaman, edited by Ihsan 'Abbas, (Beirut: Dar al-Sakafah 1970): vol. III, 71; Ibn 'Asakir, 114.

4 Sandra Campbell, “'Abdallah b. al-Zubayr” Encyclopaedia of Islam, THREE, (Brill Online 2014).

5 Jalalu'ddin Al-Suyuti, ('Abd Al-Rahman ibn Abi Bakr), History of the Caliphs (translated from the original Arabic by H.S. Jarret, Amsterdam: Oriental Press 1970): 215; Yıldız 1989, vol. II, 501.

6 Khalil Al-Sammadi, "Abdullah ibn Zubayr" in al-Rahmatu'l-muhaddatu fi-rihabi't-tufulati'-mutahhara, (Riyadh 2001): 9.

7 Ibn 'Asakir, 115; Sha'ban, 8.

8 Ibn 'Asakir, 144; Al-Shahabi, Samira, 'Abdullah bin Zubayr: al-mu'allim al-mucahid, (Cairo 1995): 6; alNatur, 18.

9 H. Ibrahim Hasan, Tarikh al-Islam, vol. I, (Beirut and Cairo 1991): 13.

10 According to Ibn Hajer (al-Isabah fi Temyizi al-Sahabah, vol. 3, Cairo 1939, 303) Asma, 'Abd Allah's mother, also accompanied her husband al-Zubay b. Awwam to the battle of Yarmuk. 
the battle from a hill (Rajab 15/August 636). Although he was not old enough to participate in the battle and fight, he gave a description of the battle in a few traditions related by him. ${ }^{1}$ He also took part in 'Amr b. Al-'As' army in the conquest of Egypt (18/639). ${ }^{2}$

His role in the conquest of Ifriqiya is worth mentioning. 'Abd Allah b. Sa'd b. Abi Sa'd, the governor of Egypt, asked permission from Caliph 'Uthman for the conquest of Ifriqiya. 'Uthman granted permission and sent him an army that included many eminent men from the companions of the Prophet. When he did not receive any news from him for some time, however, Caliph 'Uthman sent 'Abd Allah b. al-Zubayr with a group of men to find out what happened. He arrived in Ifriqiya and found that 'Abd Allah b. Sa'd was following a strategy that was giving time to the enemy to recoup. The Muslim forces were fighting the enemy until noon and then retreating because the heat was intense. He suggested that the army be divided into two groups; one group should fight in the morning and then retreat to rest while the second group should go and attack in the afternoon in order to catch the exhausted enemy resting in their tents by surprise. This plan worked, and the Muslims came out victorious after 'Abd Allah b. al-Zubayr killed Exarch Gregarious (Jarjir), the Byzantine governor of Ifriqiya, who was commanding the army (29 A.H. / 649-650 A.D.). ${ }^{3}$ He returned to Medina with a great deal of spoils of war and went to Caliph 'Uthman. 'Uthman took him to the mosque where he praised him and asked him to deliver a khutbe regarding the victory in Ifriqiya. His father al-Zubayr, soon after stepping down from pulpit, congratulated him and told him that he delivered the khutbe just like his grand father Abu-Bakr. ${ }^{4}$

The following year he took part in a campaign to Khorasan under the command of Sa'd b. Al-'As. After his return, 'Uthman appointed him one of the four scholars commissioned to make the copies of the Qur'an. 5 The Qur'an was collected and compiled during Abu Bakr's caliphate and a copy was handed over to 'Omar who passed it to his daughter Hafsa before his death, one of the wives of the Prophet. The dispute over dialectal reading forced Caliph 'Uthman to have it copied, and 'Abd Allah b. al-Zubayr along with three other scribes were ordered to

1 Ibn al-Athir, 'Izz al-Din Abi al-Hasan 'Ali b. Abi al-Karam Mohammad b. Mohammad, Al-Kamil fi al-Tarikh, (Beirut: Dar Sadir 1965): vol. II, 414; Ibn 'Asakir, 139; al-Natur, 19.

2 Al-Natur, 20.

3 Ibn 'Asakir, 138; Yıldız, H.D., “Abdullah b. Zübeyr b. Avvam,” TDV İslam Ansiklopedisi, vol. 1. (Istanbul 1988); al-Sammadi, 10-11; al-Natur, 20-21.

4 Hasan 1991, vol. I, 213; al-Shahabi 1995: 7-8; Sha'ban 1991, 17-18; al-Natur, 23; al-Kharputli, 14-16.

5 Wilferd Madelung, The Succession to Muhammad: A Study of the Early Caliphate, Cambridge: University Press, 1997: 105. 
make a copy each. ${ }^{1}$ He also took an active part in the defence of 'Uthman, not only for the whole month he was under siege. He also received about or more than ten wounds defending 'Uthman on the day he was assassinated and was the last one to leave 'Uthman's house (18 Dhi'l-hijje 35/17 June 656). ${ }^{2}$

The sources vary with regard to whether Abd Allah b. al-Zubayr held firm in the defence of 'Uthman. It is certain that he participated in his defence for a whole month and received wounds fighting the attackers. No doubt, he was sincere in defending 'Uthman as he had no inclination at the time to the office of caliphate despite the fact the people of Kufa would have liked to see his father in the office. ${ }^{3}$ Al-Zubayr b. 'Awwam, Abd Allah's father, according to Ibn al-Athir, left Medina knowing that 'Uthman was going to be killed." According to Gibb, Ibn al-Athir, when quoting passages from his predecessors, "frequently suppresses elements of the original narrative, and occasionally uses the rest to support a false interpretation." ${ }^{5}$ Hamid Mahmood, ${ }^{6}$ on the other hand, bitterly criticises Gibb and argues that Ibn Al-Athir was objective in his study of Islamic history. Carole Hillenbrand asserts that 'for a historian of his time, Ibn al-Athir was usually perceptive in his comments, often taking the trouble to analyse events as well as to record them."7 Given those circumstances then, we are unable to decide on Ibn al-Athir's motives here other than that he was probably favouring the house of Umayyads. Yet it is bizarre to think that Al-Zubayr b. 'Awwam left Medina on purpose since 'Uthman had been in constant danger for months and there was nothing to do other than

1 Ibn al-Athir, vol. III, 112; al-Natur, 30-31.

2 Ibn al-Kathir, vol. V, 262 and 268; art. "Abdullah b. Zübeyr b. Avvam,” in TDV İlam Ansiklopedisi; alNatur, 23-24; al-Kharputli, 30-31. For a detailed study of the siege of 'Uthman's house and his assassination see Madelung 1997: 784-140.

3 Ibn al-Athir, vol. III, 159; Ibn 'Asakir, 142.

4 Ibn al-Athir, vol. III, 174.

5 In reviewing the History of Crusades, particularly that of Rene Grousseté's (Paris 1934), Gibb asserts that the writers in the Ayyubid and Mamluk periods, such as Ibn al-Athir, were biased towards the Fatimid Shi'i administration. As such, in analysing a number of passages in Ibn al-Qalanisi's Damascus Chronicle and comparing them with those in Ibn al-Athir in his Kamil on the History of Crusades, Gibb asserts that Ibn al-Athir, when quoting the former writers, "frequently suppresses elements of original narrative, and occasionally uses the rest to support a false interpretation," "alters the tenor of a sentence or phrase in the original" and even intentionally regroups phrases, sentences and dates from the original source to scheme his own impression. See H. A. R. Gibb, "Notes on the Arabic Materials for the History of the Early Crusades," Bulletin of the School of Oriental Studies, University of London 7(4) (1935): 743-749.

6 Hamid Mahmood, "Understanding the World of Ibn al-Athīr: The Historian of Saladīn from Mosul," 1-16 https://www.academia.edu/8874099/Understanding_the_World_of_Ibn_alAthir_The_Historian_of_Saladin_from_Mosul, accessed on 3 November 2018.

7 Carole Hillenbrand (review by), "The Chronicle of Ibn al-Athīr for the Crusading Period from "Al-Kāmil fi' lta'rīkh," Part 1: The Years 491-541/1097-1146: The Coming of the Franks and the Muslim Response by Ibn al-Athīr, trans. D. S. Richards," Speculum 83(3) (Jul. 2008): 712-713. 
guarding him with the noble youths of Medina including al-Zubayr's son 'Abd Allah. 'Uthman's murder unfortunately gave rise to a civil war and shortly after to the division of Islamic community into the Sunni and Shi'a. ${ }^{1}$ The controversy in the Islamic community over the office of the caliphate and the concept of leadership and state was no doubt taking place in those days, and the discussions were giving rise to alternative regional groups, each of which supported a different leader. Ali supported by the Egyptians, Talha by the people of Basra, and alZubayr by the people of Kufa were the three possible candidates for the office of caliphate. ${ }^{2}$ Following 'Uthman's murder, for the Egyptians the only candidate suitable for the office of caliphate was 'Ali, while for the people of Kufa it was alZubayr, and for the people of Basra it was Talha. However, in order to avoid a schism, both the people of Kufa and of Basra followed 'Ali b. abi-Talib. Ali's strong character and his relation to the Prophet was good enough for both the Helpers (al-Ansar) and the Emigrants (al-Muhajirun) to support him for the office of the caliphate. Also, the Muslim community was aware that al-Zubayr's election to the office of the caliphate would have offended the Basrans and Talha's election would not have pleased the Kufans. ${ }^{3}$ Keshk puts forward two consecutive arguments regarding Mu'awiya ibn Abi-Sufyan's claim to the office of caliphate. First Mu'awiya had no claim to the office of the caliphate until after the Battle of Camel because those who later supported him saw that Talha and Abdullah's father alZubayr, who were killed during the battle, were more eligible for the office of the caliphate. The other argument, based on the writings of a number of scholars such as Hugh Kennedy, ${ }^{4}$ Hawting, ${ }^{5}$ Wellhausen, ${ }^{6}$ Martin Hinds, ${ }^{7}$ and Madelung, ${ }^{8}$ is that Mu'awiya could not claim the office because he-along with his allies-was not qualified, or he simply wanted to be autonomous in order to remain the governor of Syria and therefore had no claim to the office of the caliphate. He sought, rather,

1 On the medieval Muslim chroniclers' controversial approach to and debates on the assassination of Uthman see Heather Keaney, "Confronting the Caliph: "Uthmân b. 'Affân in Three 'Abbasid Chronicles," Studia Islamica 106(1) (2011): 25-48.

2 Ibn al-Athir, vol. III, 159.

Al-Kharputli, 34-35.

Hugh Kennedy, The Prophet and the Age of the Caliphate, $2^{\text {nd }}$ d. London 2004: 80.

5 G. R. Hawting, The First Dynasty of Islam: The Umayyad Caliphate, Carbondale: Southern Illinois University Press, 1987: 28-30.

6 Julius Wellhausen, Arab Kingdom and Its Fall, trans. Margaret Graham Weir, Calcutta: University of Calcutta 1927: 55-59.

7 Martin Hinds, “The Șiffin Arbitration Agreement," Journal of Semitic Studies 17 (1972): 93-113.

8 Madelung 1997: 184. 
an appointment as shura. ${ }^{1}$ This political milieu must have created two approaches in 'Abd Allah b. al-Zubayr's mind: first, to lay down a strong foundation for the office of the caliphate under the leadership of preferably a candidate from the house of the Prophet or alternatively a noble candidate supported by the majority, and second to lay down a system through which a non-imposed, a non-inherent and a non-autocratic caliph would assume the office. This is perhaps why 'Abd Allah b. al-Zubayr did not object to Mu'wiyah as a caliph but never acknowledged the office as hereditary. This concept of the caliphate and state administration was shaped and strengthened through two other major events: the Battle of Camel (15 Jumada II 36/8 December 656) ${ }^{2}$ and the Battle of Siffin (8-10 Safar 37/26-28 July 657). ${ }^{3}$ The Battle of Camel lasted only few hours while the confrontation at Siffin, apart from a few skirmishes, took three months of unavailing negotiations and ended in arbitration when the Syrians raised the Qur'an on their spears appealing for peace and talks. 'Amr b. al-'As was chosen as the Syrian representative for the arbitration, and Abu Musa al-'Ash'ari, despite 'Ali's dislike of him, was chosen as the Iraqi representative at the insistence of the qurra. 'Abd Allah b. al-Zubayr, who was convinced that Mu'awiya did not deserve the office of the caliphate, was, despite his displeasure, one of the five chosen to witness the arbitration. ${ }^{4}$ According to al-Waqidi, the arbitration took place in Sha'ban 38/January 659 when the two arbitrators met at Adhruh in northern Jordan. ${ }^{5}$ In fact, it was the qurra who had forced 'Ali to accept arbitration as part of their plan to turn the negotiations between Syria and Iraq to their own advantage. When their plan failed, they withdrew from 'Ali's army and came to be known as khawarij, those who seceded. These early khawarij, however, were not heretics and should be distinguished from all later khawarij. These early khawarij were chased and overtaken by 'Ali at Nahrawan and were persuaded to return to Kufa. Those who put up a fight were killed. For this and the next generations, these khawarij of small groups of tribesmen from various clans continued their hopeless fight, and some of these groups even had their own Amir al-Mu'minin. ${ }^{6}$

1 For details on these authors and their arguments see Khaled Keshk, "When Did Mu'āwiya Become Caliph?", Journal of Near Eastern Studies 69(1) (April 2010): 35-36.

2 Madelung 1997: 170. For the Battle of Camel and the events and intrigues that led to the battle see Madelung 1997: 141-183.

3 The battle began on Wednesday (Madelung 1997: 232). For a detailed study of the Battle of Siffin see Madelung 1997: 184-238 and al-Kharputli, 37-47.

4 Al-Kharputli: 48.

5 Madelung (1997: 283) asserts, "There is no evidence either to confirm or deny this dating." For a detailed study of the arbitration see Madelung 1997: 238-285.

6 M. A. Shaban, Islamic History: A New Interpretation A.D. 750-1055. (A.H. 132-448), (Cambridge: University Press, 1971), 74-76; Buhl, FR., "Sıffin," MEB İslam Ansiklopedisi, İstanbul: Milli Eğitim Basımevi 1967. 
It has been argued that al-Zubayr b. al-'Awwam, as one of the ten companions blessed with paradise, had claim to the office of the caliphate and therefore did not pay homage to 'Ali b. Abi-Talib, and his son 'Abd Allah inherited this aspiration. Although, according to the sources, an argument along these lines is controversial, it may well be true. However, it is equally arguable that 'Abd Allah also inherited this aspiration from his father who was appointed by 'Omar, before his death, as one of the six candidates for the caliphate. ${ }^{1}$ Therefore, it has been argued that Ibn al-Zubayr dreamt of the caliphate from his youth on. ${ }^{2}$ Yet, although 'Abd Allah along with his father al-Zubayr and Talha participated in the battle of Camel commanding the infantry, ${ }^{3}$ there is no indication that they ever objected to 'Ali's caliphate. The intrigues forced ' $A$ 'isha to participate in the campaign against 'Ali. Both the father and son were there to protect the mother of believers who was very dear to them. 'A'isha's two brothers-in-law, Talha and Al-Zubayr, were killed during the battle and 'A'isha was reprimanded and sent back to Medina. ${ }^{4}$ ' $A$ 'isha herself, it should be noted, was very careful in not causing a schism, and after the incident she withdrew from politics. The heated discussions about the death of 'Uthman and possible negligence on 'Ali's part in his defence might had been another cause for the incitement for father and son to join the campaign against 'Ali, but there was hardly any justification for them to take revenge for 'Uthman's death. Upon the order of his father al-Zubayr b. al-'Avvam, 'Abd Allah b. al-Zubayr was also present in his defence throughout ${ }^{5}$ and always safeguarded the wellbeing of 'Ali's son al-Husayn who was so keen to succeed to the office of the caliphate. 'Abd Allah b. al-Zubayr's main role in the Battle of Camel, where he received thirty-seven wounds, ${ }^{6}$ was to defend 'A'isha, his aunt and the Prophet's wife. 'A'isha did not want his mother to mourn. Despite the fact that he was like a son to her, there is hardly any evidence that she had ever incited him against 'Ali or encouraged him to seek for the office of the caliphate. It appears that his justifications for succeeding the office were developed over time and the period of civil

Al-Natur, 14 and 16.

2 Mohammed bin 'Ali Al-Hirfi, Mawqif al-Shu'ara min al-Harakah al-Zubayriyyah, (al-Hofuf, 1417 H.): $12-$ 13.

H.A.R. Gibb, “'Abd Allah b. al-Zubayr." Encyclopedia of Islam, $2^{\text {nd }}$ ed., Brill Online, 2014.

Shaban, 1971: 72

Ibrahim 1971: 33.

Ibn al-Athir, vol. III, 250-251, 262; According to Ibn Khallikan (Biographical Dictionary [Kitab Vefayatu'lA'yan], trans. from Arabic by Mac Guckin de Slane, vol. IV, Paris 1871: 536) he encountered Malik ibn alHarith, surnamed al-Ashtar al-Nakha'i. Al-Ashtar spared him because he was related to the Prophet. A'isha gave ten thousand dirhems to the person who brought her the news that he escaped with his life after an encounter with al-Ashtar. Also see al-Natur, $24 \mathrm{ff}$. 
wars. He was present when the arbitrators met at the Battle of Siffin ${ }^{1}$ and perhaps never approved the decision, although Gibb asserts that "he is said to have advised "Abd Allah b. 'Omar to bribe "Amr b. al-'As." ${ }^{2} \mathrm{He}$ must have respected Mu'awiyah, for he never took any action against him despite the fact he did not approve of him as caliph. In fact, when Mu'awiyah sent an army under the command of his son Yazid and Sufyan b. 'Awf to besiege Constantinople (49-50/669670), Ibn al-Zubayr accompanied them, along with Ibn 'Omar b. 'Abbas, Abu Ayyub el-Ansari and al-Husayn b. 'Ali. ${ }^{3}$

After 'Ali's murder, his son al-Hasan became caliph. However, al-Hasan resigned from the office in Mu'awiyah's favour (Rebi'u'l-awwal 41/July 661), fearing that, if he continued as caliph, he would cause a schism. ${ }^{4} \mathrm{Al}-\mathrm{Hasan}$, firm in his decision, threatened to lock up his brother al-Husayn if he continued inciting him to fight for the caliphate. We do not know what the impact of al-Hasan's decision on Ibn al-Zubayr was, but his later actions show that he approved of him and did not want a dispute.

'Abd Allah b. al-Zubayr himself passed sentence on his brother 'Amr and sentenced him to imprisonment in a dispute over the amount of money paid to him during the caliphate of Mu'awiyah, who claimed that the letter addressed to Ziyad for the payment and entrusted to 'Amr was opened and the amount was changed from 100,000 to 200,000 dirhem. ${ }^{5}$

'Abd Allah b. al-Zubayr did not oppose Mu'awiyah, most probably for two other reasons. First, he believed that Mu'awiyah, despite all the intrigues, deserved the office. Second, although he would have preferred to see either al-Hasan

Ibn al-Athir, vol. III, 330-331.

Gibb (“'Abd Allah b. al-Zubayr.” E/2) quoting Nasr b. Muhazim, Wak'at Siffin, Cairo 1365: 623.

Ibn al-Athir, vol. III, 459; al-Natur, 22; al-Kharputli, 62.

4 Al-Natur, 45-47. According to al-Natur $(1984,47)$ and also Yılmaz (Saim: Emeviler'de Veliahtlık, MA thesis, Marmara University, Istanbul 1996, 27-28), both quoting Ibn Qutaybah (al-Imamah ve al-Siyasah, Cairo: Maktabah al-Babi al-Halabi, vol. I, 163), al-Hasan resigned from office on condition that he would become caliph after Mu'awiyah's death. According to E.R. Fığlalı (Imamiyye Şi'ası, Istanbul: Selçuk Yayınları 1984, 88 ) this information is not reliable since it was never raised when Mu'awiyah declared his son Yazid as his successor. Al-Natur $(1984,50)$, however, continues with caution, quoting Abu al-Fida (al-Mukhtasar fi Akhbari al-Bashar, vol. I, 183) and (Al-Mas'udi, Muruj al-Dhahab, vol. III, 5) to the effect that, to nullify this condition and his promise, Mu'awiyah had al-Husayn poisoned by his wife Ja'dah binti al-Ash'as, promising her 1.000 dirhem and to marry her to his son Yazid. However, the marriage did not take place as Mu'awiyah feared for the life of his son. Campbell (“'Abdallah b. al-Zubayr” E/3), quoting al-Baladhuri and Ibn al-A'tham al-Kufi, points out that the agreement between Mu'awiyah and al-Hasan was that Mu'awiyah's successor should be elected by a shura (the consultative committee set up by 'Omar b. alKhattab to choose the caliph). In the early stages of his objection to Yazid's caliphate, Abd Allah b. Zubayr also called for shura. For further discussion see the sources cited and also Osman Nuri Dural, Mu'aviye $b$. Ebi Süfyan'a Yöneltilen Eleştiriler, M.A. thesis, Selçuk University, Konya 2007: 83-121.

5 Ibn al-Athir, vol. IV, 11. 
or al-Husayn as caliph, he was not in favour of schism and opposing Mu'awiyah. 'Abd Allah b. al-Zubayr's opinion on the matter of the caliphate appears to have carried a great weight even in the eyes of Mu'awiyah. Although Mu'awiyah had nominated his son Yazid as his successor, he was aware that any opposition from 'Abd Allah b. al-Zubayr, whom he called a lion and believed was going to be the foremost enemy of Yazid and the House Umayyads, would be very fierce. And indeed, it turned out as he feared. ${ }^{1}$

Mu'awiyah declared his son as his successor while he was still alive and asked the Muslims to pay him homage after his death. 'Abd Allah b. al-Zubayr along with al-Husayn b. 'Ali, 'Abd Allah b. 'Omar and 'Abd Ar-Rahman b. Abi Bakr, and 'Abd Allah b. 'Abbas objected to his decision. However, after obtaining the allegiance of the people of Iraq and Syria in favour of his son Yazid, Mu'awiyah left for Medina with the intention of performing the pilgrimage. The sources vary on when Mu'awiyah left and what happened first in Medina and later in Mecca.

According to various sources quoted by Yllmaz (pp. 35-37), Mu'awiyah started contemplating the idea of his son Yazid as his successor in $49 \mathrm{~A}$. H. He then left for the pilgrimage either in 50 or 51 A.H. according to al-Tabari (vol. V, 240), Ibn al-Athir (al-Kamil; vol. III, 471), Ya'qubi (vol. II, 238), Ibn Qutayba (al-Imamah, vol. I, p. 148), Mes'udi (Muruj, vol. III, 35 and 398), Khalifa b. Khayyat (p. 196), and alSuyuti (p. 196), or in 56 A.H. according to Ya 'qubi (vol. II, 238), al-Tabari (vol. V, 301), and Ibn al-Athir (al-Kamil; vol. III, 508). Prior to his pilgrimage, Mu'awiya sent a letter first to Marwan b. Hakam, his governor in Medina, to obtain his allegiance to his son as his successor. When the latter refused, Mu'awiya dismissed him in 49 A.H. and appointed Sa'd b. al-As to whom he sent several letters on the same matter. When Sa'd also declined, he left for his pilgrimage to Hijaz with a force of 1,000 men with the intention of obtaining Sa'd's allegiance to his son by force if necessary. However, according to the sources quoted by Yllmaz (p. 39) and al-Natur (1984, 64-67), ${ }^{2}$ when Mu'awiyah approached Medina, people came out to welcome him, and when al-Husayn b. 'Ali and 'Abd Allah b. 'Abbas met him at the outskirts of the city, he received them graciously. As soon as he entered the city, Mu'awiyah asked permission to visit 'A'isha, the mother of believers. He consulted her regarding his son Yazid as the next caliph. She advised him not to be hasty, as it is possible that the others may not agree with what he wanted. ${ }^{3}$ Insistent on his

1 Ibn al-Athir, vol. IV, 6. According to reports and sources, Mughirah b. Shu'bah, the governor of Kufah, indoctrinated Mu'awiyah into declaring his son as his successor. For a detailed discussion, Mu'awiyah's ventures and efforts to secure the office of caliphate for his son Yazid, and how the ground was prepared for Yazid's succession as well as the objections to his succession and the reasons behind the objections see Yılmaz, 29-47; Dural, 77-83; and al-Kharputli, 63-74, 78.

2 Cf. also Dural, 81

3 Ibn Qutaybah, vol. I, 183. 
son succeeding him and realising that he had no choice but to convince five opponents who would object to Yazid succeeding to the office, he summoned them one by one to his presence. He began with al-Husayn who told him that if the people (of Hijaz) submitted, he would be one of them ${ }^{1}$. Mu'awiyah received similar answers from the others-namely 'Abd Allah b. al-Zubayr, 'Abd Allah b. 'Omar, Abd al-Rahman b. Abi Bakr, and "Abd Allah b. 'Abbas. On the second day he called all five to his presence; 'Abd Allah b. al-Zubayr was the spokesman this time. Ibn alZubayr told him that he should follow the footsteps of the former caliphs and refrain from making the office hereditary. But Mu'awiyah, who could foresee future difficulties and was well-learned in psychology, as it is clear from his approach to the possible candidates for the office caliphate and his advice to his son Yazid on how to deal with them and the people of Iraq and Syria, ${ }^{2}$ tried to talk the five sons of eminent companions of the Prophet into submission, but they refused.

The sources vary yet again. According to Ibn Qutaybah, three men, namely 'Abd Allah b. al-Zubayr, 'Abd Allah b. 'Omar and al-Husayn b. 'Ali, and two others left for Mecca after they confronted Mu'awiyah or before his arrival. Mu'awiyah then proceeded from Medina to Mecca where, after performing pilgrimage, he called them to his presence, but the outcome did not change. ${ }^{3}$ Mu'awiyah was sure that without their allegiance the people of Mecca and perhaps of Hijaz would not submit to his son. ${ }^{4}$

The schism and dispute that was already foreseen by Mu'awiyah started after his death (15 Rajab 60/22 April 680). ${ }^{5}$ Al-Husayn b. 'Ali and 'Abd Allah b. alZubayr were in Medina at the time. Yazid, Mu'awiyah's son and successor, wrote to Al-Walid b. 'Utba b. Abi Sufyan, the governor of Medina to arrest al-Husayn, 'Abd Allah b. 'Omar, and 'Abd Allah b. al-Zubayr to obtain from them the oath of allegiance before the news of Mu'awiyah's death reached Medina. Al-Walid after seeking Marwan b. al-Hakem's advice sent 'Abd Allah b. 'Amr b. 'Uthman to summon al-Husayn and Ibn al-Zubayr to his presence in seclusion. Al-Husayn an-

1 According to another account, al-Husayn was accompanied by 'Abd Allah b. 'Abbas who told Mu'awiyah that the Prophet's close relatives and associates had the right to the office of the caliphate, see Yılmaz 1996: 40 .

2 Al-Kharputli, 76-77.

3 For detailed and conflicting information on whether Mu'awiyah used force to obtain allegiance to his son see Yılmaz 1996: 37-44.

4 Yıldız 1989, II, 310-311, 320; al-Natur, 68-69.

5 Tabarī, and I.K.A. Howard, The Caliphate of Yazīd b. Mu'āwiyah. SUNY series in Near Eastern studies. Albany, NY: State University of New York Press, 1990, 1. According to Abu 'Ali al-Qali (al-Amali, vol. 2, 313), quoted by al-Natur (p. 72), Mu'awiya said in his last khutbah delivered before he died that "no (caliph) will come to you after me except the one worse than me (من هو شر مني) just as no caliph came to you before me except the one(s) better than me (من كان خير ا مني)." 
swered the call, but with some of his close family members and the youth faithful to him, for both he and Ibn al-Zubayr feared a fatal consequence if al-Husayn did not pay homage to Yazid as caliph. Although Walid had no bad intentions, Marwan b. al-Hakem wanted to have al-Husayn killed if he did not pay homage and imprisoned if he did. Fortunately, al-Husayn, being in the company of his supporters, managed to leave unharmed. ${ }^{1}$ As for Ibn al-Zubayr, he sent his brother Ja'far to inform Walid that he would come the next day. The situation was now tense and 'Abd Allah b. al-Zubayr was convinced that al-Husayn was determined to put up a fight for the caliphate. He also believed that Yazid was not the right person for the office. $^{2}$ Therefore, to avoid meeting Walid and to find safe refuge, Ibn al-Zubayr left for Mecca with his brother Ja'far that very (Saturday three nights left in the month of Rajab 60/3 May 680) night. Mecca, he thought, was a suitable place to prepare the ground for al-Husayn's succession to the office of the caliphate. AlHusayn left Medina the following night with most of his household and also headed for Mecca (two days before the end of the month of Rajab 60/4 May 680). On the other hand, Al-Walid was not only reluctant to force al-Husayn and Ibn alZubayr into paying homage but also took no measures in preventing Ibn al-Zubayr from fleeing to Mecca except to send some eighty horsemen in their search after they had already left. ${ }^{3}$ After Ibn al-Zubayr and al-Husayn had left, al-Walid sent for 'Abd Allah b. 'Omar and asked him to give his allegiance. His reply was that "When the people give the oath of allegiance, so will I." 4 He was left alone, as they believed he would pose no danger to them.

Although 'Abd Allah b. al-Zubayr had refused to accept Mu'awiya's son Yazid as his successor, he himself had no claim to the caliphate at the time, ${ }^{5}$ despite the

1 Ibn al-Athir, vol. IV, 14-15; al-Natur, 74-75; it appears that, after paying his condolences, al-Husayn managed to delay the bay'a for two days under the pretext of arguing that it would only be valid if it was made in public. This manoeuvre gave him time to take flight to Mecca with his family (L. Veccia Vaglieri, "al-Husayn b. 'Ali b. Abi Talib" in Encyclopaedia of Islam, $2^{\text {nd }}$ ed., Brill 2014).

2 For the character of and the discussions on the suitability of Yazid's succession to the office of the caliphate and the justification for Mu'awiyah's approach to the question of the caliphate, see Yılmaz 1996: 47-55.

3 Țabarī, and Howard, 2-7; Ibn al-Athir, vol. IV, 16-17; al-Natur, 76; Al-Kahrputli, 78-82; according to alBaladhuri (Ahmad b. Yahya b. Jabir, Ansab al-Ashraf, Beirut: Dar al-Ta'arruf li al-Matbu'at 1977 [partly editedby Prof. Goitein], Jerusalem 1936, vol. IV, 13) and Tabari, Ibn al-Zubayr left Mecca on a Saturday night and al-Husayn on a Sunday night two days before the end of Rajab 60 A.H. Although conversion tables are not always accurate, it appears that $29^{\text {th }}$ of Rajab of that year corresponds to Saturday.

4 Tabarī, and Howard, 9. Al-Waqidi, however, claims al-Husayn and Ibn Zubayr left Medina the same night and on the way they met Ibn 'Omar who was coming from Mecca. Ibn 'Omar upon learning the situation in Medina and the demand for the oath of allegiance, he warned them to be pious and not to divide the Muslims. He then arrived in Medina and gave his oath of allegiance after the oath of allegiances came from other provinces. See Tabarī, and Howard, 10.

5 Campbell, "'Abdallah b. al-Zubayr” EI3. 
fact that he was one of the nominees for the office. He was fully aware that alHusayn b. 'Ali had precedence. Not having paid homage to Yazid, al-Husayn felt that he was in great danger and therefore also left (on the last Sunday in the month of Rajab 60/4 May 680) together with his family only a night after Ibn alZubayr's departure for Mecca where he was warmly welcomed. His stay in Mecca did not last long, as he feared that he was not safe from the malice of Yazid as long as he was persistent in his claim to the caliphate. Meanwhile, the people of Kufa decided to support al-Husayn who, despite being warned by 'Omar b. 'Abdurrahman b. al-Harith b. Hisham, 'Abd Allah b. 'Abbas, and 'Abd Allah b. al-Zubayr, answered the call of the people of Kufa, which led to his murder at Kerbela. ${ }^{1} \mathrm{Al}$ though 'Abd Allah b. al-Zubayr was aware that he would not be paid homage as long as al-Husayn was alive and the historians give controversial reports regarding Ibn al-Zubayr's attitude and feelings towards al-Husayn's departure for Kufa, ${ }^{2}$ there is no substantial evidence that he would have liked him to leave Mecca. In fact, it is very likely that 'Abd Allah b. al-Zubayr was preparing a base at Mecca to have al-Husayn declared caliph. ${ }^{3}$

The events attest to and reflect 'Abd Allah b. al-Zubayr's sincerity, although most historians consider that 'Abd Allah b. al-Zubayr had political motives. His support for and adherence to al-Husayn indicates that he was in actual fact opposing the Umayyad seizure of power by force rather than seeing himself as a future caliph. Likewise, al-Hirfi (p. 9) disagrees with historians who claim that Ibn alZubayr wanted to form a political party; rather, he was fighting against the Umayyads as well as all other fractions, thus forming a political party. ${ }^{4}$ In fact, Umayyads, Shi'ites, and Kharijites were political parties because they continued to exist despite their defeat and rout and adhered to a leader followed by another. Ibn alZubayr's followers believed that he was the only one suitable for the office of the caliphate, and therefore they ceased to exist, and Ibn al-Zubayr had no successor. Ibn al-Zubayr and those who gave him their allegiance stood against the Umayyad attempt to make the office of the caliphate hereditary. Ibn al-Zubayr's movement has its roots in the controversy on the caliphate following the Prophet's death, and that was revived following Abu-Bakr's death. ${ }^{5}$

1 Ibn al-Athir, vol. IV, 20; 37-38.

2 Al-Natur, 77-79. Seligshon (“Abdullah b. Zubeyr", IA) claims that Ibn Zubayr cynically advised al-Husayn to travel to Kufah. Vaglieri, ("al-Husayn b. "Ali b. Abi Talib" EI2) quoting al-Tabari (ii, 276) claims that Ibn alZubayr was harbouring secret ambitions and was therefore jealous of al-Husayn.

3 Yıldız 1989, vol. II, 322-323;

4 Hawting (The First Dynasty of Islam: The Umayyad Caliphate, AD 661-750. London, GBR: Routledge, 2000, $55)$ asserts that Ibn Zubayr left behind no program or party.

5 Al-Hirfi, 9-10. 
In Mecca, people followed al-Husayn and gathered around him listening to his speeches. 'Abd Allah b. al-Zubayr clicked to his oratory (place of prayer) beside Ka'ba and remained reluctant in taking action against those guilty of defrauding al-Husayn. Ibn al-Zubayr, supporting al-Husayn, could not have done anything other than to convince him to make an expedition to Mecca where he would be safe from the malice of Yazidis who wanted him dead (helakihi). Although Ibn alZubayr had a great reputation in Hijaz, the people swore allegiance to al-Husayn since he was a seyyid and the Prophet's grandson. ${ }^{1}$ When al-Husayn wished to travel with his family to Iraq to find supporters, both Ibn 'Abbas and Ibn al-Zubayr objected and tried to talk him out of it. ${ }^{2}$ The people of Kufa had invited him, and, unfortunately, he and his family were massacred on the way at Kerbela (Wednesday 10 Muharrem 61/10 October 680). ${ }^{3} \mathrm{Al}$-Husayn's death had a great impact not only on the people of Hijaz and Shi'a but also on Muslims in all other parts of the Islamic world, including Yazid himself who was very much moved and saddened by the assassination. All Muslims cursed both Yazid b. Mu'awiyah, who was behind the assassination, and 'Ubaydullah b. Ziyad, the assassin. According to the sources, Ibn Ziyad's mother cursed him and said "Woe unto you! ... What a crime you have perpetrated! Oh you wicked, you have killed the Prophet's (grand)son! May you never see Paradise." 4 Al-Husayn's death at Kerbela, however, paved the way for Ibn al-Zubayr.

Al-Husayn's death brought trouble with it. The people of Mecca paid homage to 'Abd Allah b. al-Zubayr. Al-Husayn's massacre must have intensified 'Abd Allah b. al-Zubayr's opposition and threat, just like the others, against the house of

1 Ibn al-Kathir, vol. V, 656.

2 However, according to the accounts in Tabari, al-Husayn was the most unwelcome of God's creatures in the eyes of Ibn Zubayr, for he believed that as long as he wass in the town, the people of Hijaz would not give him the oath of allegiance. Yet the reports in Tabari attest that al-Husayn, when travelling from Medina to Mecca, Abdullah b. Muti' advised him to stick to Harem and to be wary when approaching Kufa, for it was an unlucky place and where his father was killed. Al-Husayn himself also sent his cousin Muslim b. 'Aqil b. Abi Talib to al-Kufah, where reportedly 12,000 were ready to swear allegiance to him, to investigate whether the call was genuine. Unfortunately, the people of al-Kufah trapped and killed his cousin. Also, when travelling to al-Kufah on the way he met the poet al-Farazdak at al-Tan'im not far from Mecca who warned him about the people of Iraq to the effect that their hearts were with him, but their swords were with the Banu Umayyah. (Țabarī, and Howard, 17, 22-23, and 71; Vaglieri ("al-Husayn b. 'Ali b. Abi Talib" EI2) also quoting al-Ṭabarī, ii, 277 and 278, etc.) It is thus clear that al-Husayn was planning to travel to Iraq before he had even left Medina and, despite all the warnings, he insisted on travelling to Kufa, which eventually led to his death.

3 Ibn al-Kathir, vol. V, 665-666; Ibn al-Athir, vol. IV, 46-80; al-Natur, 77-80; Despite the fact that many tried to talk him out of travelling to Kufa, al-Husayn left Mecca for Kufa on 8 Zi'l-Hijja 60/9 September 680. Although al-Tabari, the most reliable historian, asserts that Ibn Zubayr insisted that al-Husayn stay in Mecca for his safety, some historians claim that Ibn Zubayr encouraged him to travel to Kufa. See alKharputli, 90-91.

4 Al-Natur, 82-86. 
Umayyad, although he did not take direct action against Yazid. ${ }^{1}$ He held the people of Iraq and in particular the Kufans accountable for al-Husayn's murder. ${ }^{2}$ The call to avenge al-Husayn's death also became a standard part of Shi'ite propaganda. ${ }^{3}$

Meanwhile, seeing that his position was not secure, Yazid was insistent that 'Abd Allah pay him homage. Shortly after he succeeded to the office he replaced alWalid ibn 'Utbah b. Abi Sufyan, the governor of Medina, with 'Amr b. Sa'id alAshdak, a fierce opponent of Ibn al-Zubayr.4 'Amr's hatred for 'Abd Allah b. alZubayr was so great that he appointed his brother 'Amr b. al-Zubayr head of police force (shurta). The latter already had a grudge against 'Abd Allah due to the sentence he had given him regarding his dispute with Mu'awiyah. 'Amr relentlessly persecuted those who loved his brother. His other brother al-Munzir b. alZubayr and his son Muhammed b. al-Munzir as well as notables such as 'Abdurrahman b. al-Asvad b. 'Abdi Yaghus, 'Uthman b. 'Abd Allah b. Hakim b. Hizam, and Muhammad b. 'Ammar b. Yaser were among those who were persecuted and received forty lashes. ${ }^{5}$

It is very likely that Yazid was behind these plots for it was he who ordered, in a letter to 'Amr b. Sa'id, that 'Amr b. al-Zubayr be sent with a force of two thousand men against his brother 'Abd Allah to force him pay the homage that Yazid so badly needed. In fact, the refusal of 'Abd Allah b. al-Zubayr, al-Husayn b. 'Ali, 'Abd

1 Yıldız 1989, vol. II, 22 and 489.

2 To Ibn al-Zubayr, the people of Iraq were treacherous and liars and the Kufans were the worst of all (Ṭabarī, and Howard, 189). Ibn al-Athir, vol. IV, 98.

3 Shaban 1971: 91.

4 Ibn al-Athir, vol. IV, 98. Ibn al-Athir's accounts (cf. vol. IV, 14) need to be looked at with care. Apparently, when Yazid succeeded the office of the caliphate in Rajab 60/April 680 following his father's death alWalid b. 'Utbah b. Abi Sufyan was governor of Medina, 'Amr b. Sa'id b. al-'As of Mecca, 'Ubaydullah b. Ziyad of Basra, and al-Nu'man b. Bashir of Kufa. Later the same year, Walid was dismissed as governor of Medina and replaced by 'Amr b. Sa'id (Ibn al-Athir, vol. IV, 18). Only a year later in Dhu'I-hijje 61/681 'Amr b. Sa'id, perhaps due to his failure to seize and compel Ibn Zubayr to swear allegiance to Yazid (M.J. Kister, "The battle of the Harra: Some Socio-Economic Aspects," in Studies in Memory of Gaston Wiet. Ed. Myriam Rosen Ayalon. Jerusalem: Institute of Asian and African Studies, Hebrew University of Jerusalem (1977): 35-36), was dismissed as governor of Medina and Walid b. 'Utbah was appointed in his stead (Ibn al-Athir, vol. IV, 98). However, according Ibn al-Athir's (vol. IV, 102-103) account of the Hijri year 62, Walid's governorship did not last long. After he was appointed governor of Hijaz (Medina). he tried to deceive Ibn Zubayr (perhaps in order to swear allegiance to Yazid). His plan did not work since Ibn alZubayr was cautious and taking defensive actions. Following al-Husayn's murder at Kerbela, Nejde b. 'Amir el-Nekha'iyy rebelled in Yemame and Ibn Zubayr rose up to power in Hijaz. Later, however, Nejde joined Ibn al-Zubayr and, according to public opinion, paid him homage. Ibn al-Athir further claims that Ibn Zubayr played a trick on Walid by writing a letter to Yazid in which he explained that Walid was not fit for the governorship. Therefore, Yazid dismissed Walid and replaced him with 'Uthman b. Mohammad b. Abi Sufyan. It is possible that Walid b. 'Utbah was also dismissed due to his earlier passive action in seizing al-Husayn and Ibn al-Zubayr to obtain their oaths of allegiance and allowing them to leave Medina (cf. Vaglieri, "al-Husayn b. 'Ali b. Abi Talib" EI2.)

5 Ibn al-Athir, vol. IV, 18; al-Natur, 95. 
Allah b. 'Omar, 'Abdurrahman b. Abi-Bakr and 'Abd Allah b. 'Abbas to pay homage had created resentment against Yazid. 'Amr's march onto Mecca ended in failure. He was led into Mecca without opposition, was ambushed, and then put into prison where he died later from his wounds $(61 / 681)^{1}$. 'Amr's expedition was the first series of Umayyad attempts to force Ibn al-Zubayr to accept Umayyad suzerainty or face death. ${ }^{2}$

Although the people of Mecca were displeased with the house of Umayyads and therefore had paid homage to 'Abd Allah b. al-Zubayr, the decision of 'Abd Allah b. 'Omar b. al-Khattab and 'Abd Allah b. 'Abbas b. 'Abd al-Muttalib is a puzzling one. Earlier as stated above these two eminent men, along with al-Husayn and 'Abd Allah b. al-Zubayr and 'Abdurrahman b. Abi-Bakr, objected to Mu'awiyah's attempt to seek allegiance for his son as his successor and did not even pay homage to Yazid after Mu'awiyah's death. Later, however, according to the sources quoted by al-Kharputli, ${ }^{3}$ they paid homage to Yazid b. Mu'awiyah and not 'Abd Allah b. al-Zubayr. Ibn al-Zubayr, who was badly in need of the two who were very much respected by the sons of the companions of the Prophet and the people of Mecca, to pay him homage. He therefore had to convince them to change their minds Ibn 'Abbas refused to pay homage to Ibn al-Zubayr. Yazid was relieved at his decision and sent him a letter of appreciation. Yet Ibn 'Abbas' decision was not to please Yazid but rather to avert a dispute amongst the Muslims, as he made very clear in his reply to Yazid's letter and blamed Yazid for having al-Husayn murdered. Ibn al-Zubayr also had a hard time convincing 'Abd Allah b. 'Omar to change his mind. He, therefore, had to meet Safiyya, Ibn 'Omar's wife, requesting her to convince him to declare allegiance to him. As such, although the sources are silent on this, it is possible that the people of Mecca who were most probably disturbed by these disputes were facing a dilemma: puzzled and displeased with the fact that the House of Umayyads had made the office of the caliphate hereditary, the two eminent men were refraining from declaring their allegiance to Ibn Zubayr as caliph, despite the fact they were not much in favour of Yazid b. Mu'awiyah.

The people of Medina were also displeased with the house of Umayyad for moving the political centre from Hijaz to Damascus, depriving them financially ${ }^{4}$

1 According to Tabari, 'Amr was punished and imprisoned at the order of 'Abd Allah ibn Zubayr despite the fact that the other brother 'Ubayd Allah b. al-Zubayr gave him protection (Ṭabarī, and Howard, 15-16); alNatur, 95; al-Kahrputli, 84-85.

2 Campbell, “'Abdallah b. al-Zubayr,” El3.

3 Al-Kharputli (pp. 101-103) quoting al-Bayasi, al-A'lam bi'l-Hurub al-Vaki'a fi Sadri'l-Islam (manuscript in two vols., Dar al-Kutub, the National Library of Egypt, History, nu. 399) vol. 2, folio 32, and Tarikh alYa'kubi, al-Najaf 1358 H., vol. 2, p. 221

4 Al-Kharputli, 97. 
and making the office of the caliphate hereditary. Yazid was young and inexperienced, and unlike his father he had no insight into the politics of the time. Dismissing and replacing the governors of Medina three times in a year, ${ }^{1}$ ordering 'Amr $b$. Sa'id al-Ashdak to incite 'Amr b. al-Zubayr against his brother 'Abd Allah and march on to Mecca appears to have been the cause of resentment, particularly of the people of Hijaz against him. This was an opportunity for Ibn al-Zubayr to declare Yazid deposed. The Ansar of Medina followed Ibn al-Zubayr's example and elected 'Abd Allah b. Hanzala as their chief.2 Now 'Abd Allah b. al-Zubayr was the caliph of all of $\mathrm{Hijaz}^{3}$.

\section{THE BATTLE OF HARRA}

According to al-Mes'udi, ${ }^{4}$ the people of Medina thereupon stopped obeying Yazid and swore allegiance to Ibn al-Zubayr in the year 63/683. About 1,000 Umayyads, including 'Osman b. Muhammad b. Abi-Sufyan and Mervan b. alHakam, the supporters of Yazid, left Medina, without engaging the people of Medina who came out to confront them. Disappointed with the Umayyads who fled Medina, Yazid decided to suppress Ibn al-Zubayr's movement and sent an army to punish the people of Medina and then march onto Mecca. Both 'Amr b. Sa'id and 'Ubaydu'l-lah b. Ziyad, Yazid's governor in Iraq, refused to command the army. The following year, however, Yazid, remembering his father Mu'awiyah's advice, had an army of 12,000 raised under the command of Muslim b. 'Ukbah al-Murri despite the fact that many Damascenes were reluctant to join Muslim b. 'Ukbah to fight Ibn al-Zubayr. ${ }^{5}$ He charged him with the conquest of Medina and Mecca in order to break the resistance of Ibn al-Zubayr and his supporters. Muslim b. 'Ukbah arrived at Medina in August 683 (Dhu'l-hijje 63) and gave them three days

\footnotetext{
Al-Natur, 97 and 100.

Gibb "Abd Allah b. al-Zubayr," E/2.

3 According to some sources following al-Husayn's murder Ibn al-Zubayr delivered a stimulant khutba in which he enumerated al-Husayn's merits and Yazid's misdeeds declaring him deposed as people gathered around him. He then accepted homage in secrecy. See al-Natur, 110-111; Zampaor, Mu'jam alAnsab wa al-Usar al-Hakima fi al-Tarikh al-Islami, vol. I, Cairo: Jami'at Fu'ad 1951, 27. According to Tabari (Ṭabarī, and Howard, 190), Ibn al-Zubayr had already been receiving the oath of allegiance in secrecy, and his companions following al-Husayn's death wanted him to accept the oath of allegiance publicly, but he told them not to be hasty. Baladhuri (Ansab IV/i, 304) says that he had been receiving the oath of allegiance on the basis of shura. According to al-Mes'udi (al-Kharputli, 110-111, quoting Muruj al-Zahab ve Ma'adinu'l-Javhar, vol. 3, Cairo: Matba'at-i Dar al-Rija', 16-17) the people of Medina stopped obeying Yazid and swore allegiance to Ibn Zubayr in the year 63/683. About 1,000 Umayyads, including 'Osman b. Muhammad b. Abi-Sufyan and Mervan b. al-Hakam, the supporters of Yazid, left Medina without engaging the people of Medina who came out to confront them.

4 Al-Kharputli, 110-111, quoting Muruj al-Zahab ve Ma'adinu'l-Javhar, vol. 3, Cairo: Matba'at-i Dar al-Rija', 16-17

5 Al-Kharputli, 111-112.
} 
to submit. They did not, and on 27 August (27 Dhu'l-hijje) he defeated them at the Battle of Harra. Medina fell and, although sources exaggerate, was sacked for three days. ${ }^{1}$ Many were killed. ${ }^{2}$ It has been argued that because many of those who suffered were descendants of the earliest Muslims, the anti-Umayyad propaganda exaggerated the harshness of the Umayyads and therefore the alleged sacking of the city is probably an invention ${ }^{3}$. Muslim b. 'Ukbah entered Medina, summoned the people to give the oath of allegiance to Yazid who would then dispose of their lives, property, and families as he wished, and killed anyone who refused. ${ }^{4}$ Then Muslim b. 'Ukbah, after appointing either Ravha b. Zinba' al-Juzamiyy or 'Amr b. Mahrama al-Ashja'i as his deputy in Medina, marched with his army to Mecca where 'Abd Allah b. al-Zubayr had declared himself caliph. He died on the way at Harsha, a narrow pass near a place called al-Mashallal. Al-Husayn b. Numayr took over the command as already instructed by Yazid. ${ }^{5}$ He then arrived at Mecca and put the city under siege (26 Muharrem 64/24 September 683) and bombarded it with catapults. The people of Hijaz had already paid homage to Ibn al-Zubayr and were there to help him. Those who managed to escape the siege of Medina had also joined him. The Kharijites of Yemame, under the command of Najdah (نجدة) b. 'Amir al-Hanafi had come to his help. ${ }^{6}$ According to the sources, Ibn al-Zubayr and his brother al-Munzir came out with a group of men (a force) and supporters to combat the Syrian army. Soon after the battle started, 'Abd Allah's brother al-Munzir lost his life. The Syrian army made a surprising attack, but, fortunately, 'Abd Allah's forces reconnoitred. The fighting came to a halt in the evening, and Ibn al-Zubayr withdrew his men to inside the walls of Mecca. This was the first round. The fighting continued for the rest of Muharrem and all of Safer and until 30 October 683 (3 Rabi'u'l-awwal 64). Ka'bah, Mecca bombarded with catapults, caught fire, and was burned during the siege. ${ }^{7}$ Al-Husayn b.

1 Yıldız 1989, vol. II, 504; Ibn al-Athir, vol. IV, 111-121. For a detailed analysis of the Battle of Harra see Kister, (1977): 33-49.

2 According to Yaqut (Mu'jam al-Buldan, vol. II, 249), 3,500 Mawali, 1,400 Ansar, and 1,700 Kurayshi were killed. According to al-Mas'udi (al-Tanbih wa al-Ashraf, Beirut: Dar al-Turath 1968, 264) and Ibn Qutaybah (vol. I, 198), 700 Kurayshi and 10,000 others, i.e., Mawali, al-Arab and al-Tabi'in, and according to Ibn-Qutaybah (ibid.), 80 companions of the Prophet were killed, and thus no veterans of Badr were left. See al-Natur, 90-91 and al-Kahrputli, 113-114.

3 W. Montgomery Watt, The Majesty that was Islam: The Islamic World 661-1100, (New York and Washington: Praeger Publishers, 1974): 22.

4 Tabarī, and Howard, 220. G.R. Hawting, "Yazīd (I) b. Mu'āwiya" in El2; al-Kahrputli (114) quoting Ibn alAthir (al-Kamil, vol. IV, p. 51)

5 Ibn al-Kathir, vol. V, 737; Yıldız 1989, vol. II, 504; Ibn al-Athir, vol. IV, 123; al-Natur, 91.

6 Al-Kahrputli, 114-115.

7 Al-Kharputli (115) quoting Ibn al-Athir (al-Kamil, vol. IV, 52) 
Numayr withdrew his forces after Yazid's death had been confirmed. ${ }^{1}$

Yazid's son Mu'awiyah (64/683) was a young man. ${ }^{2}$ Although the people of Damascus had paid him homage, he did not find himself fit for the caliphate and believed that both his father and grandfather had seized their right to the office of the caliphate by force. He called people to the mosque and advised them to choose someone who would be competent enough to solve the problems the Islamic State was facing. He shut himself in his house and died the same year at the age of twenty-one. His rule lasted about three months ${ }^{3}$.

The Umayyads were divided and were not very pleased with a weak ruler. Mu'awiyah's death thus strengthened Ibn al-Zubayr's position and mission. During the reign of Yazid, 'Abd Allah b. al-Zubayr had only called a council (shura') and called himself "The Refugee of the Harem/Ka'bah" (العائذ بالبيت), but, now, after Mu'awiyah's death, he started calling people to pay him homage and used the title "The Commander of the Believers" (أمير المؤمنين). The people rushed to pay him homage. ${ }^{4}$ The people of Iraq, Hijaz, and even greater part of Syria ${ }^{5}$ paid homage to 'Abd Allah b. al-Zubayr. After Al-Husayn b. Numayr's withdrawal, his recognition as caliph was wide spreading. According to al-Baladhuri, "After Mu'awiyah's death most of the people supported Ibn al-Zubayr [for the office of the caliphate] saying that he is fully grown man, had helped [and defended] 'Osman, the commander of believers, is the son of the disciple of the Prophet, his mother was the daughter of Abi-Bakr b. abi-Qahafah, the priority is his and no one else's."6 People from places such as Kufa, Basra, the northern regions of Arabia, including the

1 Ibn al-Athir, vol. IV, 123-124; Țabarī, and Howard, 223-224; Seligshon, "Abdullah b. Zubeyr", IA; Campbell, "'Abdallah b. al-Zubayr" El3; Hawting"Yazīd (I) b. Mu'āwiya” in EI2; Lammens, H. and Cremonesi, V., "al- Hușayn b. Numayr," Encyclopedia of Islam, $2^{\text {nd }}$ ed. (Leiden: Brill 2014). For Numayr's proposal to Ibn al-Zubayr to accompany him to Damascus to declare him as the sole caliph, see Yılmaz 1996, 59-61 and al-Kharputli, 118-119. According to Ibn al-Athir (vol. IV, 125) and Tabari (Ṭabarī, and Howard, 1990, 225) Yazid b. Mu'awiyah died at the village of Huwwarin near Homs on Tuesday 14 Rabi'u'l-evvel 64/10 November 683 at the age of 38 or 39 (according to al-Kharputli p. 119 at the age of 34). Accordingly, Mecca was under siege also in November. Madelung (Wilferd, 'Abd Allāh b. al-Zubayr and the Mahdī, Journal of Near Eastern Studies 40/4, 1981, 291-294) claims that a hadith in Abu Dawud's Kitab al-Sunan in the chapter on Mahdi refers to this battle, arguing that the hadith "was formulated and made public by 'Abd Allah b. al-Harith as war propaganda in support of 'Abd Allah b. Al-Zubayr."

2 According to al-Natur (120) and al-Kharputli (119) he was 18 years old and very pious.

3 Ibn al-Athir, vol. IV, 130; for details on Mu'wiyah II's resignation see al-Natur, 121-123; al-Kharputli, 119121.

4 Al-Kharputli, 122.

5 According to Madelung (1981: 293), in Syria the Qaysis allied themselves with Ibn al-Zubayr and the Kalbis with the Umayyad house.

6 Al-Kharputli p. 122 quoting al-Baladhuri, Ansabu'l Ashraf, vol. IV, Palestine 1938, 65. 
people of al-Jazirah and Syria paid him allegiance. ${ }^{1}$ The people of Jordan, where 'Ubeydullah b. Ma'mer was governor, resisted and did not pay allegiance. ${ }^{2}$ 'Abd Allah b. al-Zubayr was now very active in spreading his claim to the caliphate. He sent delegates to Egypt and Palestine and no doubt all other provinces, inviting them to accept him as caliph. To maintain his power, he appointed governors loyal to him over the provinces under his rule. ${ }^{3}$

\section{MARWAN B. AL-HAKAM AND THE BATTLE OF MARDJI RAHIT}

Although Mu'awiyah II's withdrawal from the office resulted in a split in the House of Umayyad, the eminent men of Umayyad, after long discussions, decided to pay allegiance to Marwan b. al-Hakam (27 Zi'l-ka'dah 64/16 July 684). ${ }^{4}$ With the Marwan's appointment to the office of the caliphate the lineage of Umayyad dynasty shifted from the descendants of Abu Sufyan to those of al-Hakam, both of whom were the grandsons of Umayyah. Marwan's influence, after the firm decision in his favour, increased in Syria and Jordan. Natil b. Kays, who felt insecure, fled from Palestine and joined 'Abd Allah b. al-Zubayr in Mecca. Following his flight, Marwan appointed Revha b. Zinba' as governor of Palestine. The Battle of Mardji Rahit was the turning point for Marwan and Umayyad rule. 'Abd Allah b. alZubayr had appointed al-Dahhaq b. Qays al-Fihri, the head of the Qaysi tribe, as governor of Damascus. The vice-regent ('amil) of al-Dahhaq seized the Treasury and the Bayt al-Mal and paid homage to Marwan. Marwan immediately organised a force of 13,000 men and marched against al-Dahhaq which, according to sources, had 30,000. The two armies first met in the middle of Dhu'l-hijje

1 For details on the people from those provinces that paid allegiance to Ibn al-Zubayr, see al-Kharputi, 121137.

Ibn al-Athir, vol. IV, 144.

3 Ibn 'Asakir, 158-159; al-Natur, 114-120.

4 Ibn al-Athir, vol. IV, 145-149. For details of Jabiye meetings regarding Marwan's succession to the office see Yılmaz, 62-71. All the cities except a small part of Jordan paid homage to 'Abd Allah b. al-Zubayr, while a small fraction in Syria, mostly Umayyads and their associates, paid homage to Marwan b. alHakam. The Muslim community and the scholars ('ulama) believed that 'Abd Allah b. al-Zubayr rather than Marwan b. al-Hakam (b. Abi al-'As b. Umayyah) deserved the office of the caliphate and Marwan's appointment was not legal (shar'i). Responsible for Talha's death, Marwan's past, genealogy and learning were not suitable for the office. He lacked wisdom, austerity, tradition, and convention. The Prophet had expelled Marwan's father from Medina. 'Abd Allah b. al-Zubayr and his father Zubayr b. al-'Awwam along with Talha b. 'Ubayd Allah and Marwan with their whole army had accompanied ' $A$ 'isha to Basra to confront 'Ali at the Battle of Camel. Marwan prayed behind 'Abd Allah before the battle. Shortly after the battle started Talha felt regret and decided to withdraw. Marwan, who believed that Talha was responsible for 'Othman's death, threw an arrow in guile and shot him in the thigh. Talha after the battle limped behind the army and died of his wound. See al-Kharputli, 143-144. 
64/beginning of August in 684 at Mardj al-Suffar. The Qaysis, al-Dahhaq's forces, fell back towards Damascus, but their opponents were at the foot of the Thaniyyat al-'Uqab, northeast of Damascus; this was "the encounter of Mardj Rahit." The skirmishes lasted some twenty days. The final battle, called "the day of Mardj Rahit," was on 1 Muharrem 65/18 August 684. Marwan's forces, under the command of 'Abbad b. Ziyad, defeated the Qaysis decisively. Al-Dahhaq and about 80 Damascene nobles were killed on the battlefield. The victory of Mardj Rahit meant that the worst crises were over for the Umayyads, and they gradually built up their strength. ${ }^{1}$ The Umayyad victory of Mardj Rahit was followed by the conquest of Qinnasrin, Palestine, and Homs. ${ }^{2}$ The people of Syria gradually put their trust in Marwan who then appointed his governors all over the Muslim world. ${ }^{3}$ Marwan was, in fact, taking wise steps. He did not march on to the north of Syria where the Byzantines were in power and avoided moving into Iraq where there were Shi'a and the staunch supporters of Ibn al-Zubayr were in power. Therefore, Marwan's next move, despite his old age, was to conquer grain-rich Egypt, which happened without much ado, in Jamaziya'l-ula 65/December 684. He then appointed his son 'Abd al-'Aziz as governor of Egypt. ${ }^{4}$

Marwan's next step was to send forces to attack the supporters of Ibn alZubayr near Medina and Mecca. Ibn al-Zubayr's forces, however, defeated Marwan's forces in a series of battle called Yawm al-Rabadha. Marwan died (27 Ramadan 65/7 May 685) - perhaps while these battles were going on for the control of the Hijaz. ${ }^{5}$ Marwan died before he could see the outcome of his victories and was then succeeded first by his son 'Abd al-Malik and then the other son 'Abd al'Aziz for whom he had already asked allegiance before his death. ' $\mathrm{Abd}$ al-Malik (65-86/685-705) was declared caliph after his father's death. The situation was getting worse in the Islamic world. 'Abd Allah b. al-Zubayr was still ruling Hijaz and Eastern provinces.

1 Watt 1974: 23; al-Kharputli, 141.

2 Eliséeff, N. "Mardj Rahit" in El2; al-Natur, 135-138. According to al-Natur (140), Ibn al-Zubayr was too late to act against Marwan's movements. He did not send help to al-Dahhaq who was already reluctant to pay homage to Ibn al-Zubayr. By the time Ibn al-Zubayr sent his brother Mus'ab to reconquer Palestine Marwan, before his return to Damascus, had already appointed 'Amr b. al-Sa'd b. al-'As with a strong army to encounter Mus'ab who was easily defeated. He also neglected sending forces to Egypt before Marwan undertook his campaign.

3 Ibn al-Athir, vol. IV, 151.

4 Al-Natur, 138-140.

5 Campbell, “'Abdallah b. al-Zubayr,” EI3.

6 Ibn al-Athir, vol. IV, 189-190. 


\section{AL-MUKHTAR MOVEMENT}

Al-Mukhtar b. 'Ali 'Ubayd al-Thaqafi, was regarded an 'Uthmani by the Shi'a because he proclaimed his support for Ibn al-Hanafiyya. Most probably, both his support for Ibn al-Hanafiyya and his seeking revenge for al-Husayn were the centre of his political program. ${ }^{1}$ His opposition to Umayyad rule and giving support to Muslim b. 'Aqil, who had come to Kufah in 61 A.H./680 A.D. to prepare the way for the appearance of al-Husayn, were part of his motives for his political future. In fact, his support for Muslims enraged Umayyad governor 'Ubayd Allah b. Ziyad who did not only imprison him but gave him a blow that wounded him in the eye. It was only after al-Husayn's death at Kerbala that through the intercession of his brother in law 'Abd Allah b. 'Omar who persuaded the Caliph Yazid I to order Ibn Ziyad to release him. He then left for Hijaz where 'Abd Allah b. al-Zubayr had publicly declared his opposition to Yazid's caliphate. ${ }^{2}$

According to sources, he approached 'Abd Allah b. al-Zubayr, offering him his assistance in return for a prominent position in his movement. 'Abd Allah b. alZubayr, who did not trust him refused his offer and insisted that he should swear allegiance on the same terms as the others had done. ${ }^{3}$ According to reports, he then left at some point for Ta'if where he stayed several months and developed thoughts and perhaps plans to become a political leader of Shi' ism. He returned back when al-Husayn b. al-Numayr put Mecca under siege (64 A.H./684 A.D.). He fought vigorously-as part of his political plans and motives-alongside Ibn alZubayr against the Umayyad forces. He then left for Kufa where he started to carry out his plan and political ambitons pretending that he was cooperating with Ibn al-Zubayr. According to Hawting, ${ }^{4}$ quoting al-Mas'udi, Ibn al-Zubayr even appointed him as his governor over al-Kufa, which was probably not true. ${ }^{5}$

The people of Iraq at the time were mainly divided into three different parties: the Umayyads, the Zubayrids, groups of proto-Shi'is (mainly led by alMukhtar and the tawwabun, "penitents") and various groups of Kharijites. ${ }^{6}$ This

1 Al-Mukhtar's motives no doubt were political and cynical from very start. He was manipulative and acted in accordance with the political games of the time. On the one hand, he was an ardent supporter of 'Ali, and, on the other, he did not hesitate in attempting to hand Ali's son al-Husayn, who took refuge with his uncle Sa'd b. Mas'ud, the governor of al-Mada'in, during the caliphate of 'Ali, over to his enemies the Umayyads. See G. Levi Della Vida, “Muhtar b. Abi “Ubayd al-Sakafi,” MEB İslam Ansiklopedisi, İstanbul: Milli Eğitim Basımevi, 1971.

2 G.R. Hawting, "al-Mukhtar b. Abi “Ubayd" Encyclopaedia of Islam, 2 $2^{\text {nd }}$ edition. Leiden: Brill Online, 2014; al-Kharputli, 183-184.

3 Al-Kharputli, 184.

4 Hawting, "al-Mukhtar b. Abi "Ubayd," EI2

5 Vida, "Muhtar," iA.

6 Campbell, “'Abdallah b. al-Zubayr," EI3. 
political milieu and the disunity paved the way for al-Mukhtar to revolt and overtake most of Iraq where the killing al-Husayn was still fresh in people's memories. ${ }^{1}$ At the time of his arrival (Ramadhan 64/April-May 684), the tawwabun led by Sulayman b. Surad were very active in al-Kufa. His move against Ibn Surad failed and he was again put into prison by Ibn Zubay's governor, 'Abd Allah b. Yazid al-Ansari. Apparently, Ibn 'Omar saved him again on the condition that he would not cause trouble and oppose Ibn Zubayr. However, he did not keep his promise and continued with his propaganda and managed to cooperate with Ibrahim b. al-Ashtar, the son of Ali's well-known commander Malik al-Ashtar, to revenge the death of al-Husayn after presenting him an alleged letter written by Muhammad al-Hanafiyya to accept him as his amin and vizier. ${ }^{2}$

Meanwhile, Ibn al-Zubayr replaced his governors of al-Kufah 'Abd Allah b. Yazid and Ibrahim b. Muhammad and sent 'Abd Allah b. Muti' al-Kurayshi instead. Aoon after his arrival and the delivery of his first khutbah in which he made reference to Abu-Bakr, 'Omar and 'Uthman, Ibn Muti' met him with the demand that he follow the sira of 'Ali instead of that of the first three caliphs. This paved the way for al-Mukhtar to increase the number of his supporters. ${ }^{3}$ He then took the opportunity and appealed to people for vengeance for al-Husayn, and within a short time, through his propaganda as the mahdi or saying that he had been sent by the imam, the Mahdi managed to increase the number of his supporters. He claimed that he is acting as agent and representative of Muhammad b. al-Hanafiyya, who very unlikely supported his movement. ${ }^{4}$ With the support of the Hamdani leader Ibrahim Ibn al-Ashtar al-Nakha'i, he defeated the forces of Ibn Muti', 'Abd Allah b. al-Zubayr's governor of al-Kufah. Within a short time, he was in control of the city (Rabi' al-awwal 66/October 685) and even Ibn al-Ashtar swore his allegiance to al-Mukhtar. His forces included non-Arabs (mawali) and "500 of your freed slaves (muharrarīkum)." ${ }^{5} \mathrm{He}$ eventually appointed governors over the territories dependent on al-Kufah: Armenia. Adharbaydjan, al-Mawsil, al-Mada'in, and Bihqubadh. Muhammad b. al-Ash'ath, the previous governor of al-Mawsil under Ibn al-Zubayr, first fled to Tikrit but later returned to al-Kufah and submitted to al-

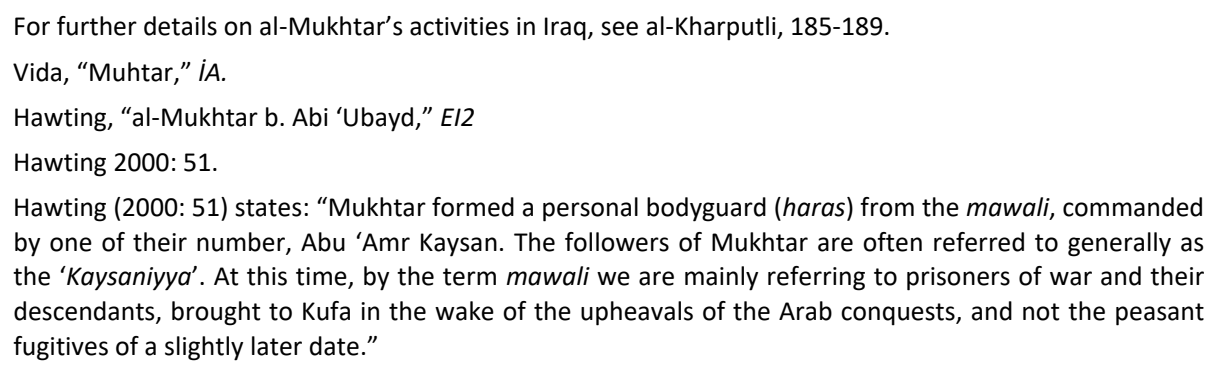
the 'Kaysaniyya'. At this time, by the term mawali we are mainly referring to prisoners of war and their descendants, brought to Kufa in the wake of the upheavals of the Arab conquests, and not the peasant fugitives of a slightly later date." 
Mukhtar. Basra and its territories remained under Ibn al-Zubayr. ${ }^{1}$

Al-Mukhtar's favourable attitude to the mawali angered some of the ashraf who started causing trouble in al-Kufah and when al-Mukhtar was forced to deal with them while Ibn al-Ashtar was away on campaign in the north, they rebelled. Ibn al-Ashtar was called back, and the rebels were crashed. The victory over the dissident ashraf was an opportunity to take the revenge of the killing of al-Husayn and his family at Karbala. Several eminent men, including 'Omar b. Sa'd b. Abi Waqqas, who had been given safe conduct by al-Muktar, were caught and killed. Meanwhile, 'Ubayda Allah b. Ziyad, who had established some control in Mesopotamia, was marching south to attack Kufa. Al-Mukhtar, again with the help of Ibn al-Ashtar, after an indecisive engagement with the Umayyad forces (D 66/July 686) defeated and killed Ibn Ziyad on the river Khazir near al-Mawsil in the following month. ${ }^{2}$

It is reported that al-Mukhtar again asked 'Abd Allah b. al-Zubayr to appoint him the governor of Iraq and Eastern provinces. 'Abd Allah b. al-Zubayr refused and thus won himself another fierce opponent. At this, Al-Mukhtar paid homage to Muhammed al-Hanafiyyah rather than 'Abd Allah b. al-Zubayr. ${ }^{3}$ The Islamic State was now divided: Syria, Palestine and Egypt were under 'Abd al-Malik, Iraq, and Al-Jazira under al-Mukhtar, and Arabia and Yemen under 'Abd Allah b. al-Zubayr.

Although al-Mukhtar had used Ibn al-Hanfiyya's name to further his cause, the relation between the two appears to have been weak. Muhammed b. alHanafiyya came to Mecca in 66 A.H./686 A.D. To strengthen his position, 'Abd Allah b. al-Zubayr asked Ibn al-Hanafiyyah, his household and followers from alKufah, to swear allegiance to him. They refused on the grounds that not all the Muslims had accepted his caliphate. Meanwhile, al-Mukhtar had already conquered al-Kufah and called people of al-Kufah to unite under Ibn al-Hanafiyya whom he had declared the mehdi. Although Ibn al-Hanafiyyah had refused the title, 'Abd Allah got alarmed and imprisoned him and his men, including 'Abd Allah b. 'Abbas, in Zemzem for having refused to recognise him as caliph, ${ }^{4}$ threatening to have them burned. They then wrote to al-Mukhtar for help. Al-Mukhtar read the letter he received in public, inciting the people against Abd Allah b. al-Zubayr and sent a cavalry of seventy men under the command of Aba 'Abd Allah b. Jadaliyy. On the way, They were joined by 'Umayr $b$. Tariq with forty men and Yunus $b$. 'Umran with another forty men. A force of one hundred and fifty entered Mecca

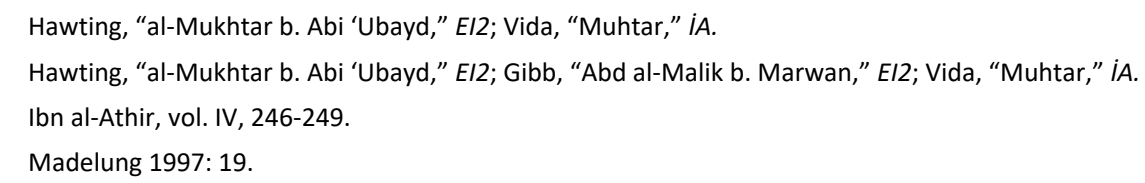


and freed al-Hanafiyyah and his men, asking permission to fight 'Abd Allah b. alZubayr. Ibn al-Hanafiyyah refused to shed blood, fearing a schism. He then left for Mina and from there to Taif, refusing 'Abd Alah's call to return to Mecca. He never again called upon al-Mukhtar for help. ${ }^{1}$

The greatest danger facing both 'Abd Al-Malik and 'Abd Allah b. al-Zubayr was, in fact, the movement of al-Mukhtar. ${ }^{2}$ However, al-Mukhtar posed a greater danger than 'Abd al-Malik to 'Abd Allah b. al-Zubayr. Believing that the fight between the Umayyad and al-Mukhtar must have weakened both sides, he decided to dismiss al-Harith b. Abi Rai'a, the governor of Basra, and appoint his brother Mus'ab b. al-Zubayr instead. ${ }^{3}$

Shortly after he defeated the forces of Ibn Muti' and taking the control of alKufah, al-Mukhtar marched onto Basra. ${ }^{4}$ Ibn al-Zubayr ordered Mus'ab to confront al-Mukhtar with his army. In the spring of 687, with the help of the Kufan ashraf, Mus'ab defeated al-Mukhtar's forces at Harūrā and chased them into al-Kufa and put him and his 6,000 supporters under siege in the palace. The siege lasted four months. Al-Mukhtar was finally forced out to fight and was killed on the battlefield (14 Ramazan 67/3 April 687). ${ }^{5}$ Although Mus'ab consolidated 'Abd Allah b. alZubay's rule in Iraq after having killed al-Mukhtar, he had to face many rebellions in the next few years that wore him out. ${ }^{6}$

The fight between 'Abd Allah b. al-Zubayr and al-Mukhtar worked in 'Abd alMalik's favour. A few years later, 'Abd la-Malik himself led an army against Mus'ab to consolidate Umayyad rule in Iraq. Having killed Mus'ab ${ }^{7}$ and defeated his forces

1 Buhl, Fr. "Muhammad Ibn al- Hanafiyya," El2; Oz, M., “Muhammed b. Hanefiyye,” TDV İslam Ansiklopedisi, vol. 30. Istanbul 2005; F.R. Buhl, "Muhammed b. al-Hanafiyya," MEB İslam Ansiklopedisi, İstanbul: Milli Eğitim Basımevi, 1971; Ibn al-Athir, vol. IV, 249-254.

2 Ibn al-Athir, vol. IV, 168-173.

3 Al-Natur, 156.

4 Ibn al-Athir, vol. IV, 266; Ibn Khallikan, vol. III, 71; According to sources, al-Mukhtar killed all those responsible for killing al-Husayn including 'Omar b. Sa ' $d$ b. Abi Waqqas. He beheaded 248 men responsible for the killing of al-Husayn before he moved on to Basra to encounter Mus'ab (al-Natur, 153-155).

5 Ibn al-Athir, vol. IV, 267-278; Hawting 2000: 53; Gibb, “Abd al-Malik b. Marwan," EI2; Vida, "Muhtar," IA For detailed information on al-Mukhtar's movement and death, see al-Natur, 148-160, and Hawting, G.R., “al-Mukhtar b. Abi “Ubayd,” E/2.

6 Sandra S. Campbell, "Famous Last Words: The Maqātil of the Zubayrids in Medieval Islamic Histories" in Journal of Arabic and Islamic Studies, 13 (2013): 63. For a detailed interpretation of al-Mukhtar's movement and the fight between him and 'Abd Allah b. al-Zubayr, see al-Kharputli, 192-1917.

7 Mus'ab's death marked the downfall of Ibn al-Zubayr's caliphate in Iraq (Campbell, "'Abdallah b. alZubayr," El3). When Abd Allah b. al-Zubayr received the news of his brother's death, he called upon the people of Mecca and addressed them, saying that his brother was a martyr, a servant of Allah, and one of his assistants, while the people of Iraq were traitorous and hypocritical (Ibn al-Athir, vol. IV, 335). This is because, after the death of the chief commander Ibrahim b. Malik al-Ashtar at the very start of the fighting, some of Mus'ab's forces abandoned their line and left Mus'ab to continue fighting with only a 
in Jamaziye'l-akhir 71/November 690 at the battle of Dayr al-Jathaliq of Maskan on the Tigris river, near a place called Awana, 'Abd al-Malik entered al-Kufah in triumph and had the people of Iraq swear allegiance to him. ${ }^{1}$ He then took further steps for the unification of Islamic State. After eliminating most of his opponents, he sent a force of 5,000 men under the command of Tariq b. 'Amr ${ }^{2}$ to Hajjaj b. Yusuf al-Thaqqafi who had camped at Ta'if (Sha'ban 72/December 691) with an army of 2,000 men. ${ }^{3}$ Tariq first marched on to Medina (Zu'l-qa'dah 72/March 692) and replaced 'Abd Allah b. al-Zubayr's man with a Damascene called Sa'labah. ${ }^{4}$

\section{HAJJAJ AND THE SIEGE OF MECCA}

After staying in Ta'if for three months, Hajjaj left for Mecca upon the arrival of the forces sent by 'Abd al-Malik. He camped at the Mount of Abu Kubays ${ }^{5}$ (southwest of Mecca) and put Mecca under siege in April (1 Dhi'l-hijje 72/24 April 692). ${ }^{6}$ It was the season for pilgrimage and Hajjaj wanted to perform the pilgrimage with his forces. 'Abd Allah b. al-Zubayr, who had already lost all of his provinces except Hijaz, refused and decided to resist Hajjaj with the people of Mecca. Hajjaj started hitting the city with catapult. However, 'Abd Allah b. 'Omar who was in Mecca at the time sent a messenger to Hajjaj asking him to stop bombarding the city with catapults until the pilgrimage was over. Hajjaj complied. Most of the pilgrims did not return to their homes and stayed to help 'Abd Allah b. al-Zubayr. The siege and the battering continued after the pilgrimage was over. The siege lasted several months-according to some sources, six or eight months; ${ }^{7}$ the food got scarce, and the people had to eat their mounts and even a dog that had been thrown in with a catapult. The prices went up: one chicken cost ten dirhems and a measure

number of men that lead to his death (art. "Abdullah b. Zübeyr b. Avvam," in TDV-iA). Campbell (2013: 63-66) quoting a number of Arab historians such as al-Baladhuri, al-Tabari, al-Mas'udi, and Ibn al-Kathir gives a detailed study of Mus'ab's death and Abd Allah b. al-Zubayr's grievance over the death of his brother and the khutbah he delivered in praise of his brother and condemning the Iraqis for betraying his brother as they had betrayed the other Muslim nobles before.

1 Ibn al-Athir, vol. IV, 323-330; al-Natur, 163-164. According to Ibn al-Athir (vol. IV, 332), 'Abd Al-Malik had Mus'ab's head cut off and sent or took it with him to Kufah and then sent it to his brother 'Abd al-'Aziz in Egypt. Mus'ab's head was then taken to Damascus where it was washed and buried. He was only thirtysix years old when he was killed.

2 Ibn al-Athir, vol. IV, 350.

3 According to Ibn al-Athir, (vol. IV, 349) Jamaziye'l-evvel 72/September 691.

4 Ibn al-Athir, vol. IV, 350. Medina changed hands several times (see al-Natur, 165-166.)

5 According to Ibn Khallikan, (vol. III, 72) he arrived at Bi'r-me'mun. Also see al-Natur, 167.

6 According to al-Karputli (220) Zu'l-qa'dah 72/March 692, the month for pilgrimage.

7 Ibn Khallikan, vol. III, 72. 
of corn twenty dirhems. ${ }^{1}$ As the siege continued and the attacks were intensified, the people estimated that about 10,000 men had left the city, fearing that their kids might die out of hunger and thirst, ${ }^{2}$ and joined forces with Hajjaj. Ibn alZubayr's two sons, Hamza and Hubayb, also deserted him. ${ }^{3}$

'Abd Allah b. al-Zubayr was sincere in his defence of the holy city. He believed that he was standing for the truth and fighting wrong. Deserted by all those around him, including his two sons, he had to choose between either continuing to defend the city with few men and thus cause further suffering and destruction to Mecca and its citizens or facing al-Hajjaj's forces on an open battlefield with a few men loyal to him. He chose the latter. After getting the permission and blessing of his mother, ${ }^{4}$ he left the city with the few men who had remained loyal to him. This seventy-two-year-old courageous man charged the forces of Hajjaj and vigorously fought to his death (14 Jemaziye'l-evvel 73/1 October 692). ${ }^{5}$ Both Ibn al-Zubayr and his youngest son were killed on the battlefield. ${ }^{6}$

Based on a forged hadith in Syria, Ibn al-Zubayr was known as the Qurayshite mulhid (deviator) on whom half of the punishment of the world would rest. Therefore, according to Basran Abu al-Siddiq al-Naji (d. 108/726-7), Hajjaj entered Mecca following his victory and went to Asma, Abd Allah's mother, and 'told her: "Surely your son deviated (alhada) in this House. God had made him taste painful punishment and has done with him what he has done." She answered: "You are lying. He was dutiful to his parents (barran li l-walidayn), fasting and praying at night continuously. By God, the Messenger of God has informed us that there shall come forth from Thaqif two archliars (kadhdhaban) the latter of them more evil

1 Al-Natur (1984: 169) quoting Ibn Kaldun, Tarikhi Ibn Khaldun, vol. 3, Beirut: Dar al-Kitab al-Lubnani 1966: 86; al-Kharputli, 228-229.

2 A. Dietrich, "al-Hadjdjaj b. Yusuf" in Encyclopaedia of Islam, $2^{\text {nd }}$ ed., Brill 2014; al-Shahabi 1995: 14.

3 Ibn al-Athir, vol. IV, 350-352; al-Natur, 168-169.

4 For a detailed study of the conversation that passed between 'Abd Allah b. al-Zubayr and his mother and the accounts of his death by various historians, such as al-Dinawari (Abū Hanīfa Aḥmad b. Dāwūd, alAkhbar al-Tiwal, ed. 'Abd al-Mun'im 'ĀMIR. Cairo: Wizā at al-thaqāfa wa-'l-irshād al-qawmī, 1960: 314 315), al-Tabari, Ibn Kathir, and al-Bladhuri regarding his death, see Campbell 2013: 66-73; also see alKharputli, 223-224.

5 Ibn al-Athir, vol. IV, 352-353; Ibn Khallikan, vol. III, 72-74; Ibn 'Asakir, 172; Seligshon, "Abdullah b. Zubeyr" IA; al-Kharputli, 226. According to Ibn al-Athir (vol. IV, 355), he received (many) wounds and died after (a few) days. In another account Ibn al-Athir (vol. IV, 356) states that they killed him on Tuesday in Jumadha'l-akher; he was seventy-three years old, and his head was cut off and taken to al-Hajjaj.

6 Dietrich, "al-Hadjdjaj b. Yusuf”, El2; For details on al-Hajjaj's siege of Mecca and 'Abd Allah b. al-Zubayr's murder see al-Kharputli, 221-226. Also, al-Kharputli's (228-245) interpretation of 'Abd Allah's defeat before al-Hajjaj and the failure of his movement is worth noticing. 
than the former as he will be a wanton destroyer (mubir)'."1 Madelung (1995), 308) then comments, "While the latter prediction of the Prophet had evidently been fulfilled in the Thaqafites al-Mukhtar and al-Hajjaj, the advent of Qurayshite mulhid was still to be expected" since it was widely unacceptable outside Syria that Ibn al-Zubayr was the Qurayshite mulhid (deviator).

Hajjaj had 'Abd Allah's head cut off and sent or, according to other accounts, he himself took it to 'Abd al-Malik b. Marwan in Syria. 'Abd al-Malik then sent Ibn al-Zubayr's head to 'Abd Allah b. al-Khazimi, who was appointed governor of Khorasan by Ibn al-Zubayr, asking him to swear allegiance to him. Ibn al-Khazimi refused and had the head washed, shrouded, and buried. According to another account, he sent it to his family in Medina to be buried along with his body. ${ }^{2}$ His body was left hanging on a tree for some time. ${ }^{3}$ His body was then given to his mother on the order of 'Abd al-Malik, and she had him buried in the house of Safiyyah near the tombs of the Prophet, Abu Bakr, and 'Omar. Hajjaj was then appointed governor of Hijaz, Yemen, and Yemame." It was after 'Abd Allah b. alZubayr's death that the caliphate of 'Abd al-Malik b. Merwan was confirmed.

\section{CONCLUSION}

'Abd Allah b. al-Zubayr had a strong character and would not easily give in to the demands such as those of al-Mukhtar, whom he hardly trusted. The Kharijites proposed helping 'Abd Allah b. al-Zubayr, providing he declared his father alZubayr and his father's friend Talha, who allegedly had incited 'A'isha against 'Ali, wrongdoers and tyrants. He refused and praised them.

A well-known figure in the world of Islam, 'Abd Allah b. al-Zubayr ruled as caliph for nine years. He was brave and very pious. He performed hajj (pilgrimage) eight times between the years 64 to 71 A.H. ${ }^{5}$ It is said that he divided the time into three: spend one night in prayer standing (qiyamen), the second night bowing (raqi'an), and the third night prostrate (sajiden). ${ }^{6} \mathrm{He}$ was well versed in Arabic and an orator (belaghe). He could speak Persian, Ethiopian, Greek, and Hebrew. ${ }^{7}$

1 Madelung, Wilferd, "'Abd Allah ibn al-Zubayr the Mulhid” in Maria Concepción Vazquez de Benito and Miguel Angel Manzano Rodriguez (eds.), Actas XVI Congreso UEAI (Salamanca 1995): 301-308; alKharputli, 227

2 Ibn Khallikan, vol. III, 74.

3 Ibn al-Athir, vol. IV, 357; al-Shahabi 1995: 14-17. Sha'ban, 1991: 26-29.

4 Ibn Khallikan, vol. III, 74.

5 Ibn 'Asakir, 161-162.

6 Ibn al-Athir, vol. IV, 360; al-Kharputli, 99.

7 Sha'ban 1991: 6. 
He had passed on about 33 hadith (traditions of the Prophet) . Of these six are in Sahih-i Buhari, two in Sahih-i Muslim, and one in both. ${ }^{1}$ He was a competent exegete of the Qur'an.2

Ka'bah caught fire and was burned and its walls fell into ruins when alHusayn al-Numayr beseiged Mecca in Muharrem 64/September 683 and bombarded it with catapults. ' 'Abd Allah b. al-Zubayr left it as it was to defame the people of Damascus, the Umayyads. But when Yezid died in November 683 and the situation in Mecca stabilised, he knocked down all four walls and had them rebuilt with two doors, one as an entrance and another as an exit, and placed the hajaru'l-eswed in its proper place, all were in accordance with the original structure planned and constructed by the Prophet Abraham himself as it was narrated in a tradition of the Prophet Muhammed transmitted by 'A'isha. ${ }^{4} \mathrm{He}$ also had the inside and outside the building perfumed. ${ }^{5}$ Hajjaj had the Ka'ba knocked down after his conquest of Mecca and had it rebuilt on the original foundation and the same dimensions as it had been before Ibn al-Zubayr's restoration. ${ }^{6}$

It is very unfortunate that both Muslim and non-Muslim historians have come up with misinterpretations of 'Abd Allah b. Zubayr and his stand against the Umayyads. This is natural due to the fact it is possible to justify the Umayyad rule on the one hand and Ibn al-Zubayr's revolt against Mu'awiya for having turned the office of the caliphate into a hereditary position. What is not acceptable is the fabrication of some hadiths to support historical facts.

In the chapter on the Mahdi of his Kitab al-Sunan, Abu Dawud al-Sijistani quotes the following prediction of the Prophet on the authority of his wife Umm Salama:

There will arise a difference after the death of a caliph, and a man of the people of Medina will go forth fleeing to Mecca. Then some of the people of Mecca will come to him and will make him rise in revolt against his will. They will pledge allegiance to him between the Rukn and the Maqam. An expedition will be sent against him from Syria but will be swallowed up (yukhsafu bihim) in the desert between Mecca and Medina. When the people see this, the righteous men (abdal)

\footnotetext{
1 Art. “Abdullah b. Zübeyr b. Avvam,” TDV IA.

For the capacity and characteristics of Ibn al-Zubayr, see al-Natur, 29-33.

3 Ibn al-Athir, vol. IV, 123-124. The historians' narratives regarding the burning of Ka'bah differ; those who blame the Umayyads, those who blame 'Abd Allah b. al-Zubayr, and those narrate a story blaming neither. For details see al-Kharputli, 248-251.

4 Ibn al-Athir, vol. IV, 207; Ibn Khallikan, vol. III, 71; al-Kharputli, 251-255.

5 Ibn Khallikan, vol. III, 71.

6 Ibn Khallikan, vol. III, 74-75. Dietrich, “al-Hadjdjaj b. Yusuf," EI2.
} 
of Syria and the troops ('asa'ib) of the people of Iraq will come to him and pledge allegiance to him. Thereafter a man of the Quraysh will arise whose maternal uncles are of Kalb. He will send an expedition against them, but they will defeat them. This will be the expedition of Kalb, and the disappointment will be for those who do not witness he spoils of Kalb. He will then divide the wealth and act among them according to the Sunna of their Prophet. Islam will settle down firmly on the ground (yulqi bi-jiranihi ila a1-ard). He will stay seven years and then die, and the Muslims will pray over him. ${ }^{1}$

Some transmitters, Abu Dawud adds, give nine years instead of seven.

It is possible that this hadith is a distortion of one of the hadiths of the Prophet who had grasped the mentality of the Arabs and the strategic importance of Mecca and Medina. Indeed, even the Byzantines kept away from the desert and used the Ghassanids as a buffer. Madelung claims that the hadith was formulated by 'Abd Allah b. al-Harith as war propaganda in support of Abd Allah b. alZubayr. ${ }^{2}$ Knowing the character of Ibn al-Zubayr, had he been aware of this, he would have definitely objected to the fabrication of such a hadith. It should be noted that most of the Prophet's hadiths are informative rather than predictive. There are, according to Western critics, a large group of forged prophecies formulated as hadiths for political reasons at a much later date in history. One such hadith concerns the killing of 'Uthman b. 'Affan. ${ }^{3}$ Because they are considered the sources of the disturbances in the Islamic world, the killing of 'Uthman, the battles of Camel and Siffin, and later the movement of Ibn al-Zubayr, have attracted the attention of both Arab and non-Arab historians and misleading interpretations backed up by hadiths.

Likewise, it is very clear in the Prophet's tradition that he very much loved his two grandsons, namely al-Hasan and al-Husayn and in this conjunction two of the Prophet's saying are striking; "whoever loves them loves me, and whoever hates them hates me" and also "al-Hasan and al-Husayn are the sayyids of the youth of Paradise." 4 Although the latter statement is important in the eyes of the Shi'ites who interpret it as the Prophet saying about al-Hasan and al-Husayn imply that they had the right to the imamate and therefore the Prophet's descendants have the right to the imamate. Yet it is very possible that the Prophet, knowing the

\footnotetext{
Madelung 1981: 291.

Madelung 1981: 292-293.

G. H. A. Juynboll, "The Date of the Great Fitna," Arabica, 20/2 (Jun. 1973), 147-148. For a detailed and critical study of this hadith, see Madelung 1995: 308.

4 See Vaglieri, "al-Husayn b. 'Ali b. Abi Talib," El2: Ibn Kathīr, viii, 205-207, has collected a fair number of these accounts, drawn mainly from the collections of Ibn Ḥanbal and of al-Tirmidhī.
} 
character of Arabs and the tribal disputes prior to the coming of Islam, could foresee rather than foretell that, due to future disturbances, his two grandsons would pass away at an early age. These two sayings most probably played a significant role in Mu'awiyah's and Ibn Zubay's considerate approach to them, for they both most probably familiar with the Prophet's sayings about them or at least that the Prophet loved them very much.

Ibn al-Zubayr in various sources is suspected of harbouring secret ambitions, and jealousy towards al-Husayn. ${ }^{1}$ Therefore, Ibn al-Zubayr could be criticised for having fled to Mecca, leaving al-Husayn behind. However, such an argument would not be valid. It is very possible that al-Husayn and Ibn la-Zubayr mutually agreed on a plan. Had they both left Medina at the same time it would have been noticed earlier, and their chances of being caught would have increased. Both came up with different but valid excuses. Although al-Husayn, who had his supporters, felt safe when he appeared before Marwan and Walid al-Hakem, Ibn alZubayr at the time had no supporters and therefore had no way of defending himself had he answered their call.

There is no evidence in the sources to support Slonger's claim that Ibn alZubayr cynically advised al-Husayn to travel to Kufa, ${ }^{2}$ Vaglieri's claim that he dissuaded him hypocritically from travelling to Kufa, ${ }^{3}$ or any evidence that his mother encouraged him to continue fighting.

1 Vaglieri, "al-Husayn b. 'Ali b. Abi Talib," in E/2.

2 See Seligshon ("Abdullah b. Zubeyr," MEB, IA).

3 Vaglieri, “al-Husayn b. 'Ali b. Abi Talib” in E/2. 


\section{References}

Abu al-Fida, Isma'il b. 'Ali b. Mahmud. al-Mukhtasar fi Akhbari al-Bashar, vol. I. Beirut: Dar al-Ma'rifah, 1956.

Al-Dinawari, Abū Hanīfa Ahmad b. Dāwūd. al-Akhbar al-Tiwal, ed. 'Abd alMun'im 'Āmir. Cairo: Wizā at al-thaqāfa wa-'l-irshād al-qawmī, 1960.

Al-Hirfi, Muhammed bin 'Ali. Mawqif al-Shu'ara min al-Harakah alZubayriyyah. al-Hofuf, $1417 \mathrm{H}$.

Al-Mas'udi, 'Ali b. al-Hasan Abu al-Hasan. al-Tanbih wa al-Ashraf. Beirut: Dar al-Turath, 1968.

Al-Mas'udi, 'Ali b. al-Hasan Abu al-Hasan. Muruj al-Dhahab. Vol. III, edited by Muhammed Muhyiddin Abdulhamid. Cairo: al-Maktabah al-Tijariyyah, 1958.

Al-Natur, Shahade. Abd Allah b. al-Zubayr ve'l-Intifade al-Sevriyye fi 'ahdi Beni Umayyah. Amman: Dar Ibn Rushd, 1984.

Al-Qali, Isma'il Abu 'Ali. al-Amali, vol. 2, Cairo: al-Maktabah al-Tijariyyah alKubra, 1954.

Al-Sammadi, Khalil, "Abdullah ibn Zubayr" in al-Rahmatu'l-muhaddatu firihabi't-tufulati'-mutahhara, Riyadh, 2001.

Al-Shahabi, Samira. 'Abdullah bin Zubayr: al-mu'allim al-mucahid. Cairo, 1995.

Al-Suyuti, Jalalu'ddin ('Abd Al-Rahman ibn Abi Bakr). History of the Caliphs. Translated from the original Arabic by H.S. Jarret. Amsterdam: Oriental Press, 1970.

Baladhuri, Ahmad b. Yahya b. Jabir, Ansab al-Ashraf. Vol. IV. Jerusalem, 1938.

Buhl, F.R., "Muhammed b. al-Hanafiyya." MEB İslam Ansiklopedisi, Istanbul: Milli Eğitim Basımevi, 1971.

Buhl, Fr. "Muhammad Ibn al- Hanafiyya," Encyclopaedia of Islam, $2^{\text {nd }}$ ed. Leiden: Brill Online, 2014.

Buhl, FR., "Sıffin." MEB İslam Ansiklopedisi, Istanbul: Milli Eğitim Basımevi, 1967.

Campbell, Sandra S. "Famous Last Words: The Maqātil of the Zubayrids in Medieval Islamic Histories." Journal of Arabic and Islamic Studies 13 (2013): 5875 .

Campbell, Sandra. Telling Memories: The Zubayrids in Islamic Historical Memory. PhD diss., UCLA ,2003.

Campbell, Sandra. "'Abdallah b. al-Zubayr." Encyclopaedia of Islam, THREE. 
Leiden: Brill Online, 2014.

Çanakçı, Kahraman. Abdullah b. Zubeyr`in hilafeti ve Emevilerle mücadelesi / The Caliphate of Abdullah b. Zubayr and his Struggle against the Umayyads. MA thesis. Ataturk University, 1996.

Dietrich, A. "al-Hadjdjaj b. Yusuf." Encyclopaedia of Islam. $2^{\text {nd }}$ ed. Leiden: Brill, 2014.

Dural, Osman Nuri, Muaviye bin Ebi Süfyan'a yöneltilen eleştiriler/ Critiques directed to Muaviye bin Ebi Sufyan. MA thesis. Konya; Selçuk University, 2007.

Eliséeff, N. “Mardj Rahit.” Encyclopedia of Islam. $2^{\text {nd }}$ ed. Leiden: Brill Online, 2014.

Er, Ahmet. Abdullah b. ez-Zübeyr ve hadis rivayetleri. MA thesis, Sakarya University, 1999.

Fığlalı, E.R. İmamiyye Şi'ası. Istanbul: Selçuk Yayınları, 1984.

Gibb, H.A.R. “'Abd Allah b. al-Zubayr." Encyclopedia of Islam, $2^{\text {nd }}$ ed. Leiden: Brill Online, 2014.

Gibb, H.A.R. "Abd al-Malik b. Marwan." Encyclopaedia of Islam, $2^{\text {nd }}$ ed. Leiden: Brill Online, 2014.

Gibb, H. A. R. "Notes on the Arabic Materials for the History of the Early Crusades." Bulletin of the School of Oriental Studies. 7(4) (1935): 739-754.

Gökçe, Arif. Abdullah b. ez-Zübeyr ve idaresi/ MA thesis. Uludağ University, 1991.

Hasan, H. Ibrahim, Tarikh Al-Islam. Vol. I. Beirut and Cairo, 1991.

Hawting, G.R. "al-Mukhtar b. Abi 'Ubayd," Encyclopaedia of Islam, 2 ${ }^{\text {nd }}$ ed. Leiden: Brill Online, 2014.

Hawting, G.R. "Yazīd (I) b. Mu'āwiya," Encyclopedia of Islam, 2nd ed. Leiden: Brill Online, 2014.

Hawting, Gerald R. The First Dynasty of Islam: The Umayyad Caliphate, AD 661-750. London: Routledge, 2000.

Hillenbrand, Carole (review by). "The Chronicle of Ibn al-Athīr for the Crusading Period from 'Al-Kāmil fi'l-ta'rīkh, Part 1: The Years 491-541/1097-1146: The Coming of the Franks and the Muslim Response by Ibn al-Athīr, trans. D. S. Richards." Speculum 83(3) (July 2008): 712-713.

Hinds, Martin. "The Șiffīn Arbitration Agreement." Journal of Semitic Studies 17 (1972): 93-113.

Hurç, Ramazan. Abdullah İbn ez-Zübeyr ve Zamanı. MA thesis. Erciyes University. 
Ibn 'Asakir. Tarikh Dimashq al-Kebir. Vol. 30, Beyrouth: Dar Ihya al-Turath al'Arabi, 2001.

Ibn al-Athir. 'Izz al-Din Abi al-Hasan 'Ali b. Abi al-Karam Mohammad b. Mohammad, Al-Kamil fi al-Tarikh. Beirut: Dar Sadir, 1965, (The version of al-Kamil used by al-Kharputli is from Cairo 1302/1884).

Ibn al-Kathir. Abu'l-Fifa al-Hafiz ibn Kathir al-Dimashqi, al-Bidayah wa alNihayah. Vol. II and V. Beirut: Dar al-Khayr, 1996.

Ibn Hajer, Shahab al-Din b. 'Ali. al-Isabah fi Temyizi al-Sahabah. Vol. 3, Cairo: al-Maktabah al-Tijariyyah, 1939.

Ibn Kaldun. Tarikhi Ibn Khaldun. Vol. 3. Beirut: Dar al-Kitab al-Lubnani, 1966.

Ibn Khallika. Biographical Dictionary (Kitab Vefayatu'l-A'yan). Trans. by Mac Guckin de Slane, vol. IV, Paris: Printed for the Oriental Translation Fund of Great Brtitain \& Ireland by Edouard Blot. 1871.

Ibn Khallikan. Vefayatu'l-a'yan ve Enba'i enba' al-Zaman. Vol. III. Edited by Ihsan 'Abbas. Beirut: Dar al-Sakafah 1970.

Ibn Qutaybah, 'Abdullah b. Muslim Ebu Muhammed,.al-Imamah wa al-Siyasah. Vol. I. Cairo: Maktabah al-Babi al-Halabi, 1963, and Beirut: Dar al-Ahya' al-Turath al-'Arabi, 1970.

Ibrahim, Sabir 'Abduh. al-Zubayr bin al-'Avvam. Kuwait, 1971.

Juynboll, G. H. A. "The Date of the great Fitna." Arabica 20(2) (June 1973): 142-159.

Keaney, Heather, "Confronting the Caliph: 'Uthmân b. 'Affân in Three 'Abbasid Chronicles." Studia Islamica 106(1) (2011): 25-48.

Keshk, Khaled. “When Did Mu'āwiya Become Caliph?” Journal of Near Eastern Studies. 69 (1) (April 2010): 31-42.

al-Kharputli, Ali Hasan. 'Abdullah b. al-Zubayr, Al-Mu'essetu al-Misriyye al'Amme, n.d.

Kister, M.J. "The Battle of the Harra: Some Socio-Economic Aspects." In Studies in Memory of Gaston Wiet. Ed. Myriam Rosen Ayalon. Jerusalem: Institute of Asian and African Studies, Hebrew University of Jerusalem (1977): 33-49. http://www.kister.huji.ac.il/content/battle-\%E1\%B8\%A5arra-some-socioeconomic-aspects.

Lammens, H. Le califat de Yazìd I er. Beirut, 1921.

Lammens, H. and Cremonesi, V., "al- Huṣayn b. Numayr." Encyclopedia of Islam, $2^{\text {nd }}$ ed. Leiden: Brill, 2014.

Madelung, Wilferd. "Abd Allah ibn al-Zubayr the Mulhid." in Maria Concep- 
ción Vazquez de Benito and Miguel Angel Manzano Rodriguez (eds.), Actas XVI Congreso UEAI (Salamanca, 1995): 301-308.

Madelung, Wilferd. "Abd Allāh b. al-Zubayr and the Mahdī." Journal of Near Eastern Studies 40/4 (1981): 291-305. (This article is reprinted in Madelung, Wilferd, Religious and Ethnic Movements in Medieval Islam, Hampshire GB and Brookfiled USA: Variorum, 1992).

Madelung, Wilferd, The Succession to Muhammad: A Study of the Early Caliphate, Cambridge:Cambridge University Press, 1997.

Mahmood, Hamid. "Understanding the World of Ibn al-Athîr: The Historian of Saladīn from Mosul." 1-16. https://www.academia.edu/8874099/Understanding_the_World_of_Ibn_alAthir_The_Historian_of_Saladin_from_Mosul. Accessed 3 November 2018

Nadvi, Syed 'Abd Allāh ibn al-Zubayr and the Caliphate, PhD diss. University of Chicago, 1972.

Nasr b. Muhazim. Wak'at Siffin. Cairo, 1365.

Oz, Mustafa. "Muhammed b. Hanefiyye." TDV İslam Ansiklopedisi, vol. 30. Istanbul, 2005.

Seligshon, M., "Abdullah b. Zubeyr." Islam Ansiklopedisi. Vol. I. Istanbul: Milli Eğitim Basımevi, 1978.

Sha'ban, Hilmi 'Ali. 'Abdullah bin al-Zubayr. Beirut, 1991.

Shaban, M. A. Islamic History: A New Interpretation A.D. 750-1055 (A.H. 132448). Cambridge: Cambridge University Press, 1971.

Tabarī, and I.K.A. Howard, The Caliphate of Yazīd b. Mu'āwiyah. SUNY Series in Near Eastern Studies. Albany, NY: State University of New York Press 1990. https://encrypted.google.com/books?id=zubkdYvBJpIC\&printsec=frontcover\&so urce $=$ gbs_ViewAPI\# $\mathrm{v}=$ onepage $\& \mathrm{q} \& \mathrm{f}=$ false.

Vaglieri, L. Veccia. "Al-Husayn b. 'Ali b. Abi Talib," Encyclopaedia of Islam. $2^{\text {nd }}$ ed. Leiden: Brill, 2014.

Vida, G. Levi Della. “Muhtar b. Abi 'Ubayd al-Sakafi.” MEB İslam Ansiklopedisi, Istanbul: Milli Eğitim Basımevi, 1971.

Watt, W. Montgomery, The Majesty that was Islam: The Islamic World 6611100. New York and Washington: Praeger Publishers, 1974.

Wellhausen, Julius. Arab Kingdom and Its Fall. Trans. Margaret Graham Weir. Calcutta: University of Calcutta, 1927.

Yaqut, Abu 'Abd Allah Shahab al-Din. Mu 'jam al-Buldan. Vol. II, Beirut: Dari Bayrut, 1956. 
Yıldız, H.D. (ed.), Büyük Íslam Tarihi. Vol. I and II, Istanbul: Çağ Yayınları, 1989.

Yıldız, H.D. “Abdullah b. Zübeyr b. Avvam.” TDV İslam Ansiklopedisi. Vol. 1. Istanbul 1988.

Yılmaz, Saim, Emeviler'de Veliahtlık. MA thesis, Marmara University, Istanbul, 1996.

Zampaor, Mu'jam al-Ansab wa al-Usar al-Hakima fi al-Tarikh al-Islami, Vol. I, Cairo: Jami'at Fu'ad, 1951. 